\title{
A revised checklist of Fijian ferns and lycophytes
}

\author{
P.J. Brownsey and L.R. Perrie \\ Museum of New Zealand Te Papa Tongarewa, P.O. Box 467, Wellington, New Zealand \\ Email:patb@tepapa.govt.nz
}

\begin{abstract}
A revised Checklist of 331 species of Fijian ferns and lycophytes is presented here. Six species are presumed to be introduced and $48(15 \%)$ are endemic. The annotated list includes family, genus and species names for all Fijian ferns, and aligns them with names used by Brownlie (1977) in his Pteridophyte Flora of Fiji. Since publication of Brownlie's work, 29 species have been added to the Fijian fern flora, 79 of the previously recorded taxa now have different generic and/or species names, and c. $40 \%$ are placed in different families. Specimens of ferns in the South Pacific Regional Herbarium (SUVA) were examined, and all have been re-identified as far as possible using the updated names. The significance of this work in the context of the wider Pacific region is discussed.
\end{abstract}

\section{Introduction}

This Checklist of ferns and lycophytes for Fiji updates the names used by Brownlie (1977) in his Pteridophyte Flora of Fiji. There have been significant changes to the taxonomy of ferns since that time, particularly with re-circumscriptions of families and genera (Smith et al. 2006). Subsequent work focused on the fern flora of Fiji includes that of Kramer \& Zogg (1988), Parris (1994), Ebihara \& Iwatsuki (2007), and the National Museum of Nature and Science (2008). Since our initial unpublished report was submitted (Brownsey \& Perrie 2008), Japanese pteridologists have published Illustrated Flora of ferns and fern allies of South Pacific Islands (National Museum of Nature and Science 2008). This book specifically covers the ferns of New Caledonia, Vanuatu, Fiji and Samoa, based on collections made by the South Pacific Fern Studies Group from 1993 to 2008. We have endeavoured to align our nomenclature with that used in their book, but have noted differences where these remain. New records for Fiji reported in their book are cited here. However, we have not had the opportunity to examine their collections which are mostly held in TNS.

There are several fern groups that require more extensive work to determine exactly what species are present in Fiji. There are a few species that probably ought to be deleted from the Flora but we cannot make such decisions without the opportunity to see cited specimens in other herbaria. There are also "species" which probably include more than one entity, and others where two or more species should be reduced to one. 
Such work is beyond the scope of the current project, but we have indicated where doubts remain.

Whilst this work is based specifically on Fiji, it does have a wider relevance for the whole of the Pacific region. Fiji is one of the larger island groups with a correspondingly large fern flora. Furthermore, it is situated midway between the Solomon Islands, whose ferns are an extension of the Malesian region, and the islands of French Polynesia in the eastern Pacific, which have a somewhat distinctive element. Providing updated names for Fijian ferns will therefore have significant benefit for many other island groups, particularly the neighbouring territories of Samoa, Tonga, Cook Islands, Niue, Vanuatu and New Caledonia. There is a considerable amount of overlap in the floristic composition of these islands. This Checklist of Fijian ferns, and particularly the annotations, will draw attention to further work that needs to be done.

\section{Materials and Methods}

We examined all the estimated 3000 sheets of Fijian ferns in the South Pacific Regional Herbarium (SUVA) at the University of the South Pacific, Suva, Fiji. Almost all sheets were assigned to folders that were annotated with the updated genus and species name. There was insufficient time for us to annotate every sheet, but sheets within each labelled folder can be appropriately re-labelled as the material is databased in future. A few sheets were considered to be unidentifiable and were labelled as such.

The only species that we did not have time to identify or sort were seven species of Selaginella. This is a particularly challenging group requiring identification with a compound microscope. We did not have the resources, time or detailed knowledge to identify the specimens of this group.

The names that we put on the folders are the currently accepted names in the attached Checklist. Some Fijian species are known only from collections in other herbaria (Brownlie 1977); specimens not represented at SUVA are indicated in the Checklist. Further information was extracted from several sources including the following:-

Papers published since 1977 that specifically identify new fern records for Fiji.

Revisions of genera and families published since 1977 that specifically include Fiji in their distributional information.

Recent Floras of neighbouring regions (e.g. Australia, New Zealand, Solomon Islands, New Caledonia, Vanuatu, Samoa, Hawai'i, etc.) that relate to Fiji.

Papers published since 1977, usually based on molecular analyses, which deal generally with the higher level classification of ferns.

We have followed Smith et al. (2006) for ferns and Christenhusz et al. (2011) for lycophytes in circumscribing families and genera, and in the arrangement of the families. Only where there is convincing contradictory evidence have we followed a different classification, and references are provided in every case. No attempt has been made to provide a classification above the level of family, although this is available from Smith et al. (2006) and Christenhusz et al. (2011).

Genera and species are arranged alphabetically within families for ease of use. Descriptions for most species are given in Brownlie (1977). However, where new 
records have been accepted, reference is given to the publication establishing a Fijian presence, to any cited specimens and to a published description. Species presumed to be introduced to Fiji are identified.

In the Checklist itself we have retained Brownlie's names unless there is a good reason to change them. The list is annotated to indicate all such changes at family, genus and species level. References to modern revisions are provided. In addition, we have indicated instances where other authors have suggested possible synonymies and alternative names, or where there is uncertainty in the literature. It was beyond the scope of this project to undertake taxonomic revisions to confirm these suggestions, but the notes highlight genera and species that should be investigated if such work was to be carried out.

Three alphabetical appendices of names are provided to correlate the names used by Brownlie with our list:-

1. Names used by Brownlie linked to their currently accepted names.

2. New records for Fiji published since 1977.

3. Doubtful records and possible synonymies mentioned in the notes, linked to their currently accepted names.

\section{Taxonomic treatment}

A revised total of 331 species is listed here. Of these, four are either undescribed or of uncertain species identity. In making changes to Brownlie's nomenclature, we have adopted a conservative approach. Nevertheless, since 1977, 29 species have been newly recorded for Fiji, and 79 of the previously recorded taxa now have different generic or species names - about $33 \%$ of the currently recognised fern flora. In addition, about $40 \%$ of the species are now placed in different families compared to Brownlie's treatment.

Of the total of 331 species, 6 are presumed to be introduced and 48 are regarded as endemic to Fiji. The latter is just $15 \%$ of the total and compares with a figure of $46 \%$ for the New Zealand fern flora (Brownsey 2001). The research conducted by Japanese pteridologists in the South Pacific (National Museum of Nature and Science 2008) has greatly reduced the number of endemic species recognised by Brownlie (1977) but we suspect that future work in the region will reduce this proportion still further.

${ }^{\mathrm{E}}$ Species endemic to Fiji

* Species considered to be introductions

$\wedge$ Species not definitely represented in SUVA

Herbarium abbreviations follow Thiers (2011).

NMNS (2008) is used as an abbreviated reference for National Museum of Nature and Science (2008)

\section{LYCOPODIACEAE}

We follow the classification of Øllgard (1987) recognising Huperzia, Lycopodium and Lycopodiella in Fiji, rather than the single genus Lycopodium listed by Brownlie (1977). 
HUPERZIA Bernh.

Huperzia carinata (Desv. ex Poir.) Trevis.

Huperzia foliosa (Copel.) Holub

E Huperzia magnifica (Brownlie) Holub

Glenny (unpub.) strongly advocates including the Fijian endemic H. magnifica under $H$. dalhousieana (Spring) Trevis. which is distributed through Malesia and the west Pacific. However, this requires confirmation, as Chinnock (1998a) indicates that $H$. dalhousieana extends no further east than New Guinea.

Huperzia melanesica (Brownlie) Holub

Huperzia nummulariifolia (Blume) Jermy

Huperzia parksii (Copel.) Holub

Huperzia phlegmaria (L.) Rothm.

$\wedge$ Huperzia phlegmarioides (Gaud.) Rothm.

Recorded by NMNS (2008) but without citing a specimen. A description is given by Chinnock (1998a).

Huperzia phyllantha (Hook. et Arn.) Holub

Huperzia serrata (Thunb. ex Murray) Trevis.

Brownlie (1977) only records one specimen for Fiji, in BM (of which he saw a photograph), but there are now other specimens in SUVA. Not listed by NMNS (2008).

Huperzia squarrosa (G.Forst.) Trevis.

${ }^{\mathrm{E}}$ Huperzia subtrifoliata (Brownlie) Holub

${ }^{\mathrm{E}}$ Huperzia trifoliata (Copel.) Holub

$\wedge$ Huperzia sp. 1

Recorded and illustrated as an undescribed species by NMNS (2008) (TNS 9520650).

\section{LYCOPODIUM L.}

\section{Lycopodium clavatum L.}

LYCOPODIELLA Holub

Lycopodiella cernua (L.) Pic.Serm.

\section{SELAGINELLACEAE}

We follow the treatment of Selaginella in Fiji by Gardner (1997). Selaginella hordeiformis Baker was recorded by NMNS (2008) without reference to a specimen, but this species was specifically excluded by Gardner.

SELAGINELLA P.Beauv.

E Selaginella breynioides Baker

Selaginella distans Warb.

Selaginella firmula A.Braun ex Kuhn

\section{Selaginella laxa Spring}

Gardner (1997) suggests that this species is only dubiously distinct from S. ciliaris (Retz) Spring, but nevertheless retains it for Fiji. Glenny (unpub.) reduces it to synonymy with S. ciliaris, whilst Jermy \& Holmes (1998) indicate that S. ciliaris 
extends into the west Pacific but make no mention of S. laxa. The relationship of these two species needs further investigation.

Selaginella rechingeri Hieron. ex Rech.

Selaginella victoriae T.Moore

E Selaginella viridangula Spring

OPHIOGLOSSACEAE

BOTRYCHIUM Sw.

$\wedge$ Botrychium daucifolium Wall. ex Hook. et Grev. Brownlie 907, cited by Brownlie (1977), is in CHR (340891!). NMNS (2008) state "Botrychium daucifolium is recorded from Fiji and Western Samoa. We could not find it from both islands". Consequently, they do not list it, but we retain it here on the basis of Brownlie's specimen in CHR.

\section{OPHIOGLOSSUM L.}

Ophioglossum pendulum L.

$\wedge$ Ophioglossum petiolatum Hook.

O. petiolatum is often reduced to synonymy with $O$. reticulatum, but the two are retained here because of Brownlie's statement that they appear to be restricted to different ecological conditions in Fiji. DA 14540 cited by Brownlie (1977), is in CHR (340890!).

\section{Ophioglossum reticulatum $\mathrm{L}$.}

\section{PSILOTACEAE}

PSILOTUM Sw.

Psilotum complanatum Sw.

Psilotum nudum (L.) P.Beauv.

TMESIPTERIS Bernh.

Tmesipteris truncata (R.Br.) Desv.

NMNS (2008) also record T. oblanceolata Copel. but this is now regarded as a synonym of T. truncata (Chinnock 1998b).

\section{EQUISETACEAE}

\section{EQUISETUM L.}

Equisetum ramosissimum Desf. subsp. debile (Roxb.) Hauke

Hauke (1963) refers Fijian material of E. ramosissimum to subsp. debile. Brownlie (1977) misspelt the specific epithet as "ramossisimum".

\section{MARATTIACEAE}

\section{ANGIOPTERIS Hoffm.}

\section{Angiopteris evecta (G.Forst.) Hoffm.}

Var. evecta and var. vaupelii Hieron. are both recognised in Fiji by NMNS (2008) but without citing specimens. These varieties were not discussed by Brownlie (1977), and the key in NMNS (2008) suggests a lack of clear distinguishing characters. They require further investigation. 
$\wedge$ Angiopteris opaca Copel.

Brownlie (1977) stated that this species is known only from the Fijian type in $\mathrm{MICH}$ and differs from A. evecta by its degree of scaliness. However, NMNS (2008) indicate that they collected this species from Vanuatu and Samoa, as well as Fiji.

PTISANA Murdock

Ptisana smithii (Mett. ex Kuhn) Murdock

Treated by Brownlie (1977) in Marattia.

\section{OSMUNDACEAE}

LEPTOPTERIS C.Presl

Leptopteris wilkesiana (Brack.) H.Christ

\section{HYMENOPHYLLACEAE}

Brownlie (1977) recognised two large genera of filmy ferns - Hymenophyllum and Trichomanes - and we follow his classification. However, Ebihara et al. (2006) subdivided Trichomanes into eight separate genera, and their alternative names are given if this treatment is preferred.

\section{HYMENOPHYLLUM J.Sm.}

\section{Hymenophyllum denticulatum Sw.}

Hymenophyllum feejeense Brack.

Hymenophyllum flabellatum Labill.

Hymenophyllum holochilum (Bosch) C.Chr.

Brownlie (1977) treated this species as H. affine Brack. but Ebihara \& Iwatsuki (2007) have shown that it is a synonym of H. holochilum.

\section{Hymenophyllum imbricatum Blume}

\section{Hymenophyllum javanicum Spreng.}

Brownlie (1977) recognised $H$. samoense Baker as also being in Fiji but this is synonymised with $H$. javanicum by NMNS (2008).

$\wedge$ Hymenophyllum macgillivrayi (Baker) Copel.

Recorded by Ebihara \& Iwatsuki (2007), based on the type specimen collected by Macgillivray from Fiji (K). A description is given by Copeland (1937).

$\wedge$ Hymenophyllum multifidum (G.Forst.) Sw.

Recorded by Ebihara \& Iwatsuki (2007) but without citing a specimen. A description is given by Copeland (1937).

$\wedge$ Hymenophyllum pallidum (Blume) Ebihara et K.Iwats.

Recorded by NMNS (2008) but without citing a specimen. A description is given by Bostock \& Spokes (1998a).

Hymenophyllum polyanthos (Sw.) Sw.

$\wedge$ Hymenophyllum serrulatum (C.Presl) C.Chr.

Recorded by Ebihara \& Iwatsuki (2007) but without citing a specimen. A description is given by Copeland (1937) as H. meyenianum (C.Presl) C.Chr.

$\wedge$ Hymenophyllum tomaniiviense (Brownlie) Ebihara et K.Iwats.

Described as Trichomanes "tomaiiviense" by Brownlie (1977) but this is a spelling 
error (Ebihara et al. 2006). The species is treated in Hymenophyllum by Ebihara et al. (2006). Only one possible, unlocalised specimen was seen in SUVA. The holotype, Brownlie 1776, is in CHR (340646!).

\section{TRICHOMANES L.}

Trichomanes aphlebioides $\mathrm{H}$.Christ syn. Crepidomanes aphlebioides (H.Christ) I.M.Turner

Trichomanes apiifolium C.Presl syn. Callistopteris apiifolia (C.Presl) Copel.

Trichomanes asae-grayi Bosch syn. Abrodictyum asae-grayi (Bosch) Ebihara et K.Iwats.

Trichomanes atrovirens (C.Presl) Kunze (Fig. 1a) syn. Cephalomanes atrovirens C.Presl Brownlie (1977) treated this species as Trichomanes boryanum Kunze, but NMNS (2008) synonymised it with T. atrovirens (as Cephalomanes atrovirens C.Presl).

Trichomanes bimarginatum Bosch syn. Didymoglossum bimarginatum (Bosch) Ebihara et K.Iwats.

Trichomanes bipunctatum Poir. syn. Crepidomanes bipunctatum (Poir.) Copel.

E Trichomanes caespifrons C.Chr. Needs a new combination if treated as Abrodictyum. Not recognised by NMNS (2008).

Trichomanes caudatum Brack. syn. Abrodictyum caudatum (Brack.) Ebihara et K.Iwats.

Trichomanes dentatum Bosch syn. Abrodictyum dentatum (Bosch) Ebihara et K.Iwats. Glenny (unpub.) treats Trichomanes dentatum and T. obscurum Blume as one variable species under T. obscurum, but Murdock \& Smith (2003) recognise T. dentatum. This requires further investigation.

Trichomanes endlicherianum C.Presl syn. Polyphlebium endlicherianum (C.Presl) Ebihara et K.Iwats.

Trichomanes humile G.Forst. syn. Crepidomanes humile (G.Forst.) Bosch

Trichomanes intermedium Bosch syn. Crepidomanes intermedium (Bosch) Ebihara et. K.Iwats.

Trichomanes maximum Blume syn. Vandenboschia maxima (Blume) Copel.

Trichomanes minutum Blume syn. Crepidomanes minutum (Blume) K.Iwats. Brownlie (1977) recognised Trichomanes saxifragoides C.Presl but this is included within one polymorphic species, T. minutum (syn. Crepidomanes minutum), by Yoroi \& Iwatsuki (1977), Ebihara et al. (2006) and NMNS (2008).

$\wedge$ Trichomanes motleyi Bosch syn. Didymoglossum motleyi (Bosch) Ebihara et K.Iwats. Brownlie (1977) treated this species as Trichomanes cultratum Baker, but this was synonymised with T. motleyi (as Didymoglossum motleyi) by NMNS (2008). 


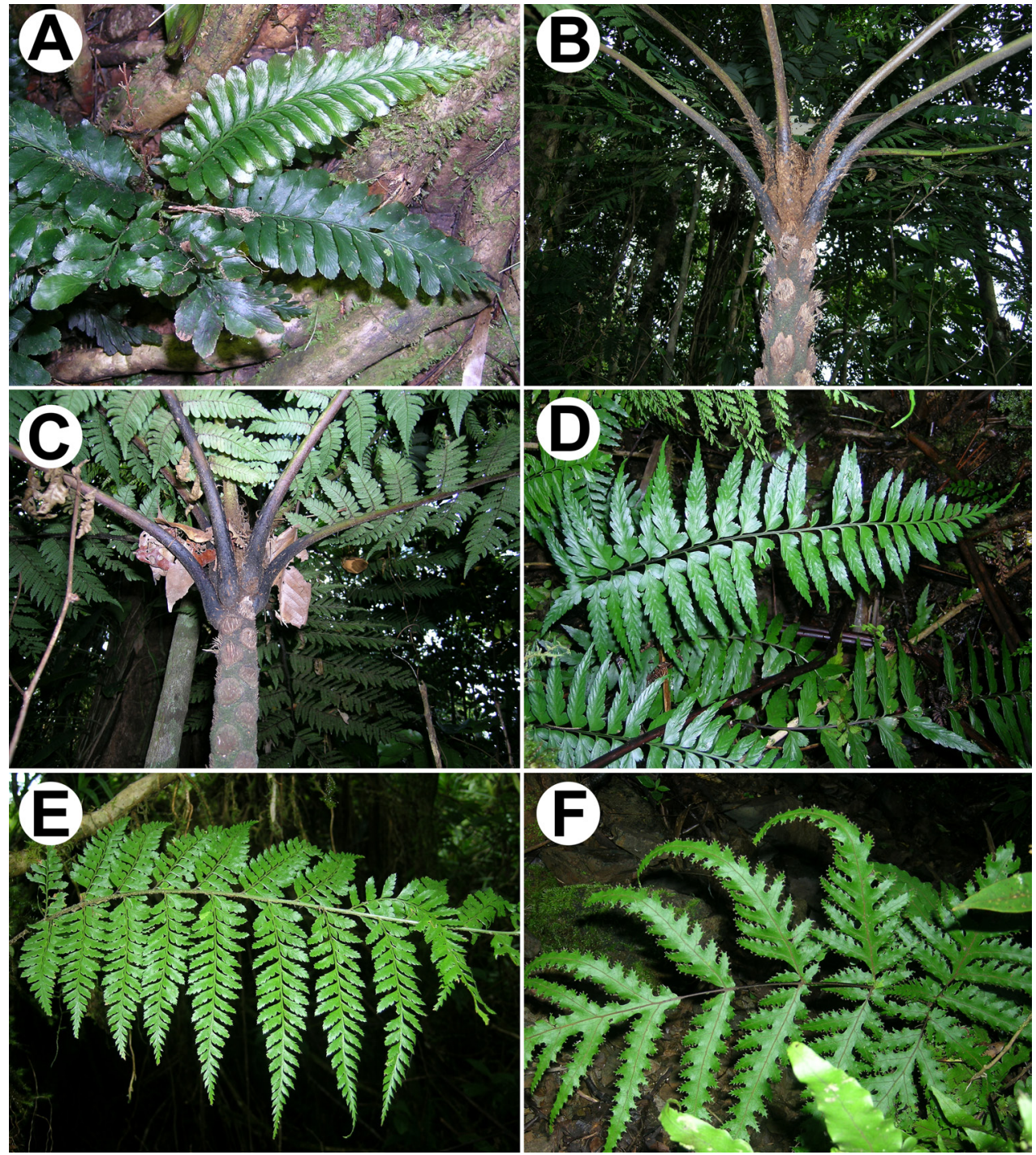

Fig. 1. Ferns of Fiji. a, Trichomanes atrovirens (WELT P022770). Treated as Trichomanes boryanum by Brownlie (1977) and as Cephalomanes atrovirens by NMNS (2008); b, the Fijian endemic Cyathea microlepidota, whose longer stipes distinguish it from the otherwise similar C. propinqua; c, the Fijian endemic Cyathea propinqua; d, Asplenium lobulatum (WELT P022796). Recorded for Fiji by Parris (1994), having been previously misidentified as A. polyodon, A. insiticium, or as hybrids between the two by Brownlie (1977); e, Polystichum aff. moluccense (WELT P022791), following Parris (1994). Listed as P. aculeatum by Brownlie (1977); f, the Fijian endemic Tectaria godeffroyi (WELT P022774), with its distinctive marginal sori. 
Trichomanes tahitense Nadeaud syn. Didymoglossum tahitense (Nadeaud) Ebihara et K.Iwats

$\wedge$ Trichomanes vitiense Baker syn. Crepidomanes vitiense (Baker) Bostock.

Known from Fiji only by the type in $\mathrm{K}$.

\section{GLEICHENIACEAE}

Brownlie (1977) recognised only two genera of umbrella ferns in Fiji - Gleichenia and Dicranopteris - but, following Smith et al. (2006), we recognise Diplopterygium and Sticherus in place of Gleichenia sens. lat.

DICRANOPTERIS Bernh.

${ }^{\mathrm{E}}$ Dicranopteris caudata (Copel.) H.St.John

$\wedge$ Dicranopteris curranii Copel.

Collected and recorded by NMNS (2008) (TNS 9521360). A description is given by Holttum (1959).

Dicranopteris linearis (Burm.f.) Underw.

It is unclear which variety of this species Fijian material should be referred to.

DIPLOPTERYGIUM (Diels) Nakai

Diplopterygium longissimum (Blume) Nakai

Included by Brownlie in Gleichenia sens. lat.

STICHERUS C.Presl

Sticherus oceanicus (Kuhn) H.St.John

Included by Brownlie in Gleichenia sens. lat.

\section{DIPTERIDACEAE}

Dipteris was included in the Polypodiaceae by Brownlie (1977) but is now generally included in its own family (Smith et al. 2006).

DIPTERIS Reinw.

Dipteris conjugata Reinw.

\section{LYGODIACEAE}

Brownlie (1977) included Lygodium within Schizaeaceae, but Lygodiaceae is recognised as a separate family by Smith et al. (2006).

LYGODIUM Sw.

$\wedge$ Lygodium microphyllum (Cav.) R.Br.

Recorded and collected by NMNS (2008) but without citing a specimen. A description is given by Chinnock (1998c).

Lygodium reticulatum Schkuhr

SCHIZAEACEAE

SCHIZAEA SM.

Schizaea dichotoma (L.) Sm.

$\wedge$ Schizaea fistulosa Labill.

Only one sterile specimen (Wilson 7), cited by Brownlie (1977), was seen in SUVA.

Schizaea melanesica Selling 


\section{SALVINIACEAE}

SALVINIA Ség.

* Salvinia molesta D.S.Mitch.

Recorded as S. auriculata Aubl. by Brownlie (1977) but almost certainly the Fijian plant is referable to the rampant tropical Kariba weed (Mitchell 1972). All specimens in SUVA are sterile and cannot be identified with certainty.

\section{CYATHEACEAE}

Smith et al. (2006) recognise four genera amongst those species included within Cyathea by Brownlie (1977), but we recognise them at the subgeneric level following Large \& Braggins (2004). Alternative names in Alsophila, Gymnosphaera and Sphaeropteris are provided where they exist.

\section{CYATHEA Sm.}

Cyathea affinis (G.Forst.) Sw.

syn. Alsophila tahitensis Brack. (non A. affinis Fée)

Cyathea alta Copel.

syn. Alsophila alta (Copel.) R.M.Tryon

Confused with the unrelated C. alata (E.Fourn.) Copel. from New Caledonia by NMNS (2008).

Cyathea decurrens (Hook.) Copel.

Cyathea hornei (Baker) Copel. syn. Gymnosphaera hornei (Baker) Copel.

Cyathea lunulata (G.Forst.) Copel. subsp. vitiensis (Carruth.) Holttum syn. Sphaeropteris lunulata (G.Forst.) R.M.Tryon

NMNS (2008) also record Cyathea lunulata subsp. lunulata without citing a specimen. However, the infraspecific treatment of $C$. lunulata needs further investigation before accepting both subspecies in Fiji. The combination for subsp. vitiensis in Sphaeropteris has not been made.

Cyathea medullaris (G.Forst.) Sw.

syn. Sphaeropteris medullaris (G.Forst). Bernh.

Whether Fijian material is the same as the New Zealand species requires further investigation.

${ }^{\mathrm{E}}$ Cyathea microlepidota Copel. (Fig. 1b) syn. Sphaeropteris microlepidota (Copel.) R.M.Tryon

Not listed by NMNS (2008). Based on specimens in SUVA and our own field observations, Cyathea microlepidota (Fig. 1b) and C. propinqua (Fig. 1c) are clearly distinct from one another and other tree ferns in Fiji.

${ }^{\mathrm{E}} \wedge$ Cyathea plagiostegia Copel.

syn. Alsophila plagiostegia (Copel.) R.M.Tryon

Known only from the type in BISH and one barely fertile specimen in SUVA. Distinguished from C. affinis only by size and a darker indusium. Requires further investigation.

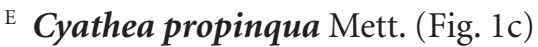
syn. Sphaeropteris propinqua (Mett.) R.M.Tryon

Not listed by NMNS (2008). Based on specimens in SUVA and our own field 
observations, Cyathea microlepidota (Fig. 1b) and C. propinqua (Fig. 1c) are clearly distinct from one another and other tree ferns in Fiji.

$\wedge$ Cyathea subsessilis Copel.

syn. Sphaeropteris subsessilis (Copel.) R.M.Tryon

Collected once in Fiji and differs from C. propinqua only in size and scale type. Not listed by NMNS (2008), and requires further investigation.

Cyathea truncata (Brack.) Copel.

syn. Sphaeropteris truncata (Brack.) R.M.Tryon

\section{DICKSONIACEAE}

Brownlie (1977) included all the tree fern genera in Cyatheaceae, but following Smith et al. (2006) we recognise Dicksoniaceae as a separate family from Cyatheaceae.

CALOCHLAENA (Maxon) M.D.Turner et R.A.White

Maxon (1922) described Culcita blepharodes from material collected in Fiji by the Wilkes Expedition. White \& Turner (1988) regarded it as a synonym of the Australian endemic Calochlaena dubia (R.Br.) M.D.Turner et R.A.White, being either incorrectly attributed to Fiji or an introduction from Australia. No other Fijian specimens are known, and Brownlie (1977) did not mention Maxon's species. Its presence in Fiji requires confirmation.

Calochlaena straminea (Labill.) M.D.Turner et R.A.White

This species was included in Culcita by Brownlie (1977), but White \& Turner (1988) transferred it to the new genus Calochlaena.

DICKSONIA L'Hér.

Dicksonia brackenridgei Mett.

\section{LINDSAEACEAE}

LINDSAEA Dryand. ex Sm.

Lindsaea agatii (Brack.) Lehtonen et Tuomisto

Recognised by Brownlie (1977) as a subspecies of L. ensifolia but raised to species rank by Lehtonen et al. (2010).

Lindsaea gueriniana (Gaudich.) Desv.

Not listed by Kramer (1970) for Fiji but recorded by Brownlie (1977) "for the first time ... in a very restricted area ... near the summit of Mt Korobaba" supported by two specimens. Not listed by NMNS (2008).

Lindsaea harveyi Carruth. ex Seem.

Lindsaea lapeyrousei (Hook.) Baker

Listed as Lindsaea lapeyrousii subsp. fijiensis K.U.Kramer by Brownlie (1977), but Lehtonen et al. (2010) corrected the spelling to L. lapeyrousei and rejected the subspecies. The species was not listed by NMNS (2008), but is accepted here following Lehtonen et al. (2010).

Lindsaea moorei (Hook.) E.Fourn.

Lindsaea obtusa J.Sm. ex Hook.

Brownlie (1977) states that this species has been collected only once in Fiji, and is otherwise distributed from Taiwan and Micronesia to Queensland. Kramer 
(1970) notes that it is largely replaced in the Pacific by L. harveyi. Glenny (unpub.) suggests that there is only one variable species. The presence of L. obtusa in Fiji therefore needs confirmation. There are two possible collections in SUVA. Not listed by NMNS (2008).

Lindsaea pacifica K.U.Kramer

Lindsaea pickeringii (Brack.) Mett. ex Kuhn

$\wedge$ Lindsaea propinqua Hook. in Night.

Very dubiously recorded for Fiji by Kramer (1970) on the basis of two poorly localised 19th century collections in US. Accepted by Brownlie (1977) but not listed by NMNS (2008).

Lindsaea pulchra (Brack.) Carruth. ex Seem. var. pulchra

${ }^{\mathrm{E}}$ Lindsaea pulchra (Brack.) Carruth. ex Seem. var. protracta (Copel.) Brownlie

$\wedge$ Lindsaea repens (Bory) Thwaites var. marquesensis E.D.Br.

Brownlie (1977) recognised, but did not list, any specimens of var. marquesensis; however, Kramer (1970) cites seven Fijian collections.

Lindsaea repens (Bory) Thwaites var. sessilis (Copel.) K.U.Kramer

Based on DNA sequence analysis, Lehtonen et al. (2010) raised L. repens var. sessilis to species rank as L. sessilis Copel., and suggested that many of the other varieties of $L$. repens might warrant the same status. However, they did not analyse var. marquesensis and its correct rank remains uncertain. Both Fijian taxa are therefore retained here as varieties of $L$. repens until a full analysis is completed.

Lindsaea rigida J.Sm.

Lindsaea tetragona K.U.Kramer

${ }^{\mathrm{E}}$ Lindsaea vitiensis K.U.Kramer

ODONTOSORIA Fée

Odontosoria chinensis (L.) J.Sm.

Treated in Sphenomeris by Brownlie (1977), but referred to Odontosoria by Lehtonen et al. (2010).

TAPEINIDIUM (C.Presl) C.Chr.

Tapeinidium denhamii (Hook.) C.Chr.

Tapeinidium melanesicum K.U.Kramer

\section{SACCOLOMATACEAE}

Brownlie (1977) regarded these species as belonging to Orthiopteris in the Dennstaedtiaceae. We follow Smith et al. (2006) in treating them as Saccoloma in the Saccolomataceae.

SACCOLOMA Kaulf.

E Saccoloma ferulaceum (T.Moore) R.M.Tryon et A.F.Tryon

Saccoloma tenue (Brack.) Mett.

\section{DENNSTAEDTIACEAE}

Brownlie (1977) recognised Dennstaedtiaceae and Hypolepidaceae but, following Smith et al. (2006), we include them both within the Dennstaedtiaceae. Schuettpelz \& Pryer (2007) found Dennstaedtia to be strongly polyphyletic, suggesting that the generic classification of this group needs further investigation. 
DENNSTAEDTIA Bernh.

Dennstaedtia flaccida (G.Forst.) Bernh.

Dennstaedtia glabrata (Ces.) C.Chr.

E Dennstaedtia inermis (Baker) Brownlie

HISTIOPTERIS (Thunb.) J.Sm.

Histiopteris incisa (Thunb.) J.Sm.

${ }^{\mathrm{E}}$ Histiopteris sinuata (Brack.) J.Sm.

Glenny (unpub.) suggests H. stipulacea (Hook.) Copel. (Malesia), H. sinuata (Fiji), H. integrifolia Copel. (Manus Island) and H. herbacea Copel. (Solomon Islands) could all be regarded as a single species, and this requires further investigation. Note that while the stipules in $H$. sinuata are greatly reduced, they are not absent as stated by Brownlie (1977).

HYPOLEPIS Bernh.

Hypolepis elegans Carruth.

$\wedge$ Hypolepis tenuifolia (G.Forst.) Bernh. ex C.Presl

Brownlie (1977) described this species as H. nausoriensis. NMNS (2008) followed his treatment, but the name was reduced to synonymy under $H$. tenuifolia by Brownsey (1987). The type of H. nausoriensis is in CHR!

MICROLEPIA C.Presl

Microlepia speluncae (L.) T.Moore

$\wedge$ Microlepia strigosa (Thunb.) C.Presl

Known from a single collection in UC from near Nadarivatu.

E Microlepia vitiensis Brownlie

PTERIDIUM Gled. ex Scop.

Pteridium esculentum (G.Forst.) Cockayne

\section{PTERIDACEAE}

We follow Smith et al. (2006) in recognising the large family Pteridaceae, in contrast to Brownlie (1977) who assigned this group to Vittariaceae and Adiantaceae. Stenochlaena, included here by Brownlie, is now recognised in Blechnaceae.

\section{ACROSTICHUM L.}

\section{Acrostichum aureum L.}

Acrostichum speciosum Willd.

Recorded by Parris (1994), and accepted here, but not listed by NMNS (2008). A description is given by Kramer \& McCarthy (1998).

\section{ADIANTUM L.}

${ }^{*}$ Adiantum capillus-veneris $\mathrm{L}$.

Recorded by NMNS (2008) without citing a specimen. The identity of this species needs confirmation (cf. A. tenerum Sw.) but it appears to be well established in Suva. There is also a specimen in SUVA from "Naitasiri, forest behind Sawani village, Brownlie 774". A description of A. capillus-veneris is given by Bostock (1998a). 


\section{Adiantum diaphanum Blume}

Adiantum hispidulum Sw.

${ }^{\mathrm{E}}$ Adiantum hornei Baker

\section{Adiantum philippense L.}

Treated as A. lunulatum Burm.f. by Glenny (unpub.).

\section{* Adiantum trapeziforme L.}

This species appears to be well established in several places in the south of Viti Levu. There are also two specimens in SUVA from "Ba, Mt Natobilibili, hill slope 1900 ft, D. Koroiveibau, 10.4.1965 (14198)" and "Viti Levu, Nadroga, Nagalemarie, S. Vodonaivalu 1614, 8.8.1989". It was recorded by NMNS (2008) without citing a specimen. A description is given by Mickel \& Smith (2004).

\section{ANTROPHYUM Kaulf.}

\section{Antrophyum alatum Brack.}

Glenny (unpub.) includes this species under A. callifolium Blume, but PichiSermolli (1991) and Jones (1998c) treat them as separate species, and A. alatum is retained here.

Antrophyum plantagineum (Cav.) Kaulf.

Antrophyum semicostatum Blume

$\wedge$ Antrophyum smithii C.Chr. in A.C.Sm.

Known only from specimens in BISH and US according to Brownlie (1977), but collected and recorded by NMNS (2008).

Antrophyum subfalcatum Brack.

CERATOPTERIS Brongn.

* Ceratopteris thalictroides (L.) Brongn.

CHEILANTHES Sw.

$\wedge$ Cheilanthes farinosa (Forssk.) Kaulf.

Brownlie (1977) recorded this species for Fiji on the basis of a "somewhat doubtful identification" of a single collection in K from west-central Viti Levu. This specimen needs checking to determine if it should be identified as Pityrogramma calomelanos, now recognised as adventive in Fiji (see below).

Cheilanthes nudiuscula (R.Br.) T.Moore

Listed as C. hirsuta (Poir.) Mett. by Brownlie (1977) but reduced to synonymy under C. nudiuscula by Chambers \& Farrant (1998).

Cheilanthes tenuifolia (Burm.f.) Sw.

CONIOGRAMME Fée

Coniogramme fraxinea (D.Don) Diels

DORYOPTERIS J.Sm.

Doryopteris concolor (Langsd. et Fisch.) Kuhn 
MONOGRAMMA Schkuhr

Monogramma paradoxa (Fée) Bedd.

Recognised by Brownlie (1977) and NMNS (2008) as Vaginularia angustissima but included in the synonymy of Monogramma paradoxa by Christensen (1906). Vaginularia is reduced to synonymy with Monogramma by Smith et al. (2006).

\section{PITYROGRAMMA Link}

$\wedge *$ Pityrogramma calomelanos (L.) Link

This species was seen by us in southern Viti Levu, and was collected and recorded by NMNS (2008) (TNS 9528567). Note comments under Cheilanthes farinosa (above). A description of Pityrogramma calomelanos is given by Bostock (1998a).

\section{PTERIS L.}

Pteris comans G.Forst.

Pteris ensiformis Burm.f.

Pteris excelsa Gaudich.

Pteris litoralis Rech.

Pteris mertensioides Willd.

$\wedge$ Pteris milneana (Hook.) Baker

Included within P. tripartita by Brownlie (1977), but recorded separately by Parris (1994) and accepted here. A diagnosis is given by Copeland (1929).

$\wedge$ Pteris multifida Poir.

Collected and recorded by NMNS (2008) (TNS 9509957). A description is given by Li et al. (1975).

Pteris pacifica Hieron.

E Pteris parhamii Brownlie

Described as a new endemic species by Brownlie (1977), but included within $P$. werneri (Rosenst.) Holttum by Glenny (unpub.). Brownlie's name is retained here, but needs further investigation.

\section{$\wedge$ Pteris tremula $\mathrm{R} . \mathrm{Br}$.}

Known only from a single collection in BISH from Kadavu according to Brownlie (1977), but also recorded by NMNS (2008) without citing a specimen.

Pteris tripartita Sw.

${ }^{\mathrm{E}}$ Pteris vitiensis Baker

Pteris vittata L.

SYNGRAMMA J.Sm.

Syngramma borneensis (Hook.) J.Sm.

E Syngramma spathulata (C.Chr.) Holttum

TAENITIS Willd. ex Schkuhr

Taenitis blechnoides (Willd.) Sw. is listed for Fiji by Holttum (1968), Kato (1988), Bostock (1998a) and Glenny (unpub.) but specifically excluded by Brownlie (1977, p. 6). No specimens are cited by these authors, and none were seen in SUVA. Its presence in Fiji therefore needs confirmation.

Taenitis hookeri (C.Chr.) Holttum

Taenitis pinnata (J.Sm.) Holttum var. pinnata 
Taenitis pinnata (J.Sm.) Holttum var. brachysora (Baker) Holttum

E Taenitis pinnata (J.Sm.) Holttum var. polypodioides (Baker) Holttum

VITTARIA Sm.

Vittaria elongata Sw.

Vittaria scolopendrina (Bory) Thwaites

\section{ASPLENIACEAE}

Brownlie (1977) recognised both Asplenium and Loxoscaphe in Fiji, but we follow Smith et al. (2006) in reducing Loxoscaphe to synonymy under Asplenium, and accepting Hymenasplenium as a segregate genus.

\section{ASPLENIUM L.}

Asplenium amboinense Willd.

Asplenium australasicum Hook.

Asplenium bipinnatifidum Baker

Asplenium carruthersii Baker

Noted by Glenny (unpub.) as similar to A. oligolepidum C.Chr. of New Caledonia.

Asplenium caudatum G.Forst.

Asplenium cuneatum Lam.

Asplenium gibberosum (G.Forst.) Mett.

Treated by Brownlie (1977) in Loxoscaphe, but now generally included in Asplenium.

${ }^{\mathrm{E}}$ Asplenium induratum Hook.

Asplenium insiticium Brack.

Asplenium laserpitiifolium Lam.

Glenny (unpub.) suggests that the relationship of this species to A. neolaserpitiifolium Tardieu et Ching and A. pseudolaserpitiifolium Tardieu et Ching requires further investigation.

Asplenium lobulatum Mett. ex Kuhn (Fig. 1d)

Recorded by Parris (1994). Several specimens in SUVA belong to this species, but were previously misidentified as A. polyodon, A. insiticium, or as hybrids between the two (as discussed by Brownlie 1977, p. 217). A description is given by Christensen (1943).

Asplenium marattioides (Brack.) C.Chr.

Asplenium nidus $\mathrm{L}$.

Asplenium polyodon G.Forst.

${ }^{\mathrm{E}}$ Asplenium stenolobum C.Chr.

Treated as Loxoscaphe foeniculaceum (Hook.) T.Moore by Brownlie, but now generally included in Asplenium. Christensen (1906) proposed A. stenolobum as a nomen novum for this species because of an earlier homonym. Should be compared with Samoan material, especially A. powellii Baker.

Asplenium tenerum G.Forst.

HYMENASPLENIUM Hayata

Hymenasplenium excisum (C.Presl) S.Linds.

Treated as Asplenium excisum C.Presl by Brownlie (1977) but now included in Hymenasplenium. 
Hymenasplenium unilaterale (Lam.) Hayata

Treated as Asplenium unilaterale Lam. by Brownlie (1977) but now included in Hymenasplenium.

\section{THELYPTERIDACEAE}

Following Holttum (1971), Brownlie (1977) recognised nine genera of Thelypteridaceae in Fiji. His classification is accepted here, with the addition of Chingia and Pseudophegopteris recorded by Parris (1994).

CHINGIA Holttum

$\wedge$ Chingia sp. 1 aff. imponens (Ces.) Holttum

Collected, recorded and illustrated by NMNS (2008) (TNS 9527705, 9527706, 9523655).

$\wedge$ Chingia longissima (Brack.) Holttum

Recorded by Parris (1994). A description is given by Holttum (1977).

CHRISTELLA H.Lév.

Christella arida (D.Don) Holttum

Christella dentata (Forssk.) Brownsey et Jermy

Christella harveyi (Mett.) Holttum

Christella pacifica Holttum

Christella parasitica (L.) H.Lév.

Christella subpubescens (Blume) Holttum

CORYPHOPTERIS Holttum

Coryphopteris seemannii Holttum

$\mathrm{E} \wedge$ Coryphopteris vitiensis Holttum

Specimens cited by Brownlie (1977), including Brownlie 900, 1777 (isotype, CHR 339288 ) and $D A 18769 A$, are in CHR!

\section{CYCLOSORUS Link}

Cyclosorus interruptus (Willd.) H.Itô

Listed as C. tottus (Thunb.) Pic.Serm. by Brownlie (1977), but treated as C. interruptus by Holttum (1977).

MACROTHELYPTERIS (H.Itô) Ching

Macrothelypteris polypodioides (Hook.) Holttum

Macrothelypteris torresiana (Gaudich.) Ching

PLESIONEURON (Holttum) Holttum

NMNS (2008) indicated that there was a previous record of Plesioneuron attenuatum (Brack.) Holttum from Fiji, but did not collect a specimen themselves or cite an earlier reference. Holttum (1975) regarded this species as distributed from "Bismarck Archipelago to Tahiti", but did not cite any Fijian specimens. Brownlie did not record the species in Fiji and hence its occurrence there is unsubstantiated.

E Plesioneuron archboldiae (Copel.) Holttum

Plesioneuron hopeanum (Baker) Holttum

Plesioneuron prenticei (Carruth.) Holttum 


\section{PNEUMATOPTERIS Nakai}

Pneumatopteris costata (Brack.) Holttum

Pneumatopteris magnifica (Copel.) Holttum

P. transversaria (Brack.) Holttum is listed for Fiji by Holttum (1977) but Fijian material is reduced to synonymy with P. magnifica by Brownlie (1977).

E Pneumatopteris parksii (F.Ballard) Holttum

PRONEPHRIUM C.Presl

Glenny (unpub.) and Bostock (1998b) list P. asperum (C.Presl) Holttum for Fiji but without any cited specimens. However, it is not listed by Brownlie (1977) or by Holttum (1977) for the Pacific, and its presence in Fiji remains unsubstantiated.

Pronephrium beccarianum (Ces.) Holttum

Pronephrium rubrinerve (Mett.) Holttum

Pronephrium triphyllum (Sw.) Holttum

\section{PSEUDOPHEGOPTERIS Ching}

$\wedge$ Pseudophegopteris paludosa (Blume) Ching

Described as P. fijiensis Kramer et Zogg (1988) (holotype Z, isotype K) but reduced to synonymy with $P$. paludosa by Parris (1994). Its relationship to P. persimilis (Baker) Holttum from Samoa needs further study. Only one possible specimen seen in SUVA.

\section{SPHAEROSTEPHANOS J.Sm.}

Sphaerostephanos decadens (Baker) Holttum

Listed as Cyclosorus decadens by Brownlie (1977).

Sphaerostephanos heterocarpus (Blume) Holttum

Listed as Cyclosorus suprastrigosus (Rosenst.) Copel. by Brownlie (1977), but treated as S. heterocarpus and later reduced to synonymy by Holttum $(1977,1981)$.

Sphaerostephanos invisus (G.Forst.) Holttum

Sphaerostephanos unitus (L.) Holttum

\section{WOODSIACEAE}

This group was previously included in Athyriaceae by Brownlie (1977), but is treated in the Woodsiaceae by Smith et al. (2006).

DEPARIA Hook. et Grev.

Deparia boryana (Willd.) M.Kato

Treated in Lunathyrium by Brownlie (1977) but transferred to Deparia by Kato (1984).

E Deparia gordonii (Baker) M.Kato

Treated in Lunathyrium by Brownlie (1977) but transferred to Deparia by Kato (1984).

$\wedge$ Deparia japonica (Thunb.) M.Kato

Collected, recorded and illustrated by NMNS (2008) (TNS 9523481), in addition to $D$. petersenii. Descriptions distinguishing the two are given by Kato (1984). 
Deparia petersenii (Kunze) M.Kato

Treated as Lunathyrium japonicum (Thunb.) Sa.Kurata by Brownlie (1977) but Fijian material was placed in Deparia petersenii by Kato (1984).

DIPLAZIOPSIS C.Chr.

Diplaziopsis javanica (Blume) C.Chr.

\section{DIPLAZIUM Sw.}

Diplazium bulbiferum Brack.

Glenny (unpub.) also lists D. dameriae Pic.Serm. for Fiji, but cites no specimen. Pichi Sermolli (1991) confirms the two species are different, but lists only $D$. bulbiferum from Fiji. All material in SUVA is similar to D. bulbiferum with eroded basiscopic pinnules, and no sign of auricles as in D. dameriae.

Diplazium dietrichianum (Luerss.) C.Chr.

Treated as Diplazium esculentum (Retz.) Sw. by Brownlie. Diplazium dietrichianum is listed for Fiji by Jones (1998a), separating it from D. esculentum sens. str. by the vein pattern, but no specimen is cited. All Fijian specimens in SUVA and CHR have the vein pattern of $D$. dietrichianum. Diplazium esculentum may also be present in Fiji, but this needs confirmation. Some CHR specimens labelled by Brownlie as D. esculentum approach $D$. dilatatum.

Diplazium dilatatum Blume

Diplazium echinatum C.Chr.

E $\wedge$ Diplazium gillespiei (Copel.) M.Kato

Treated as Lunathyrium gillespiei by Brownlie (1977) but transferred to Diplazium by Kato (1984). Recorded by Brownlie from a single collection in US from Namosi, but also collected and recorded by NMNS (2008) (TNS 9522685).

Diplazium harpeodes T.Moore

Diplazium melanocaulon Brack. var. melanocaulon

Diplazium melanocaulon Brack. var. coriaceum (Carruth. ex Seem.) Brownlie

Diplazium proliferum (Lam.) Kaulf.

Brownlie (1977) attributes the authority for this combination to du Petit-Thouars but, as explained by Ballard (1955), the combination was not validly made, and the correct citation is Diplazium proliferum (Lam.) Kaulf., Enum. Filic. 182 (1824).

\section{BLECHNACEAE}

\section{BLECHNUM L.}

Blechnum chambersii Tindale

Treated as B. doodioides (Brack.) Brownlie by Brownlie (1977), but this is a later homonym of $B$. doodioides Hook. Parris (1980) reinstated the name B. chambersii. The relationship of this species to B. norfolkianum (Heward) C.Chr. needs further investigation.

E Blechnum difforme Copel.

$\wedge^{*}$ Blechnum gibbum (Labill.) Mett.

Recorded only once from an unlocalised specimen in BISH. Considered by Brownlie (1977) to be possibly naturalised. 
Blechnum melanocaulon (Brack.) T.C.Chambers et P.A.Farrant

Treated as B. coriaceum (Brack.) Brownlie by Brownlie (1977) and NMNS (2008) but reduced to synonymy with B. melanocaulon by Chambers \& Farrant (2001).

Blechnum milnei (Carruth.) C.Chr.

\section{Blechnum orientale L.}

Blechnum pilosum (Brack.) Brownlie

Brownlie (1977) suggests this may be a race of B. vulcanicum (Blume) Kuhn, but Chambers \& Farrant (2001) note that some forms of B. vulcanicum outside Malesia warrant separate taxonomic status. Fijian material needs further investigation.

E Blechnum vittatum Brack.

DOODIA R.Br.

Molecular evidence suggests that Doodia is nested within Blechnum (Shepherd et al. 2007), and that a new generic classification is required within Blechnaceae.

Doodia brackenridgei Carruth. ex Seem.

$\wedge$ Doodia media R.Br.

Recorded by NMNS (2008) but without citing a specimen. A description is given by Parris (1998).

\section{STENOCHLAENA J.Sm.}

Included by Brownlie (1977) in Adiantaceae, but now treated in the Blechnaceae (Smith et al. 2006).

Stenochlaena palustris (Burm.f.) Bedd.

\section{HYPODEMATIACEAE}

Reinstated by Christenhusz et al. (2011) for Didymochlaena, Hypodematium, and Leucostegia, after being included tentatively in the Dryopteridaceae by Smith et al. (2006); also see Schuettpelz \& Pryer (2007). Brownlie (1977) included Didymochlaena in his Aspidiaceae and Leucostegia in the Davalliaceae.

DIDYMOCHLAENA Desv.

Didymochlaena truncatula (Sw.) J.Sm.

LEUCOSTEGIA C.Presl

Leucostegia pallida (Mett.) Copel.

\section{DRYOPTERIDACEAE}

The Dryopteridaceae, as construed by Smith et al. (2006), includes genera that were mostly placed in either the Aspidiaceae or Lomariopsidaceae (Bolbitis, Elaphoglossum and Lomagramma) by Brownlie (1977).

ACROPHORUS C.Presl

Acrophorus nodosus C.Presl

Listed as A. blumei Ching ex C.Chr. by Brownlie (1977) but A. nodosus is an earlier valid name (fide Parris et al. 1992).

ARACHNIODES Blume

Arachniodes aristata (G.Forst.) Tindale 


\section{BOLBITIS Schott}

Bolbitis quoyana (Gaudich.) Ching is recorded for Fiji by Hennipman (1977), and listed by Jones (1998b) and Glenny (unpub.), but specifically excluded by Brownlie (1977, p. 6). It may have been confused with B. vanuaensis.

Bolbitis lonchophora (Kunze) C.Chr.

Included as B. palustris (Brack.) Hennipman by Brownlie (1977), but reduced to synonymy under B. lonchophora by Hennipman (1977). The author citation is given incorrectly as "(Fée) C.Chr." by Hennipman.

Bolbitis rivularis (Brack.) Ching in C.Chr.

Recorded as a hybrid ( $\times$ rivularis) by NMNS (2008) but without any indication of parentage. Its status requires further investigation.

Bolbitis vanuaensis Brownlie

This species was described by Brownlie (1977) and may be the same species as that identified as B. quoyana by Hennipman and other authors, but the descriptions of the width of the fertile pinnae do not match. Requires further investigation.

CTENITIS (C.Chr.) C.Chr.

E Ctenitis fijiensis (Hook.) Copel.

${ }^{\mathrm{E}} \wedge$ Ctenitis minima Brownlie

The generic position of this species is unclear. It is known only from the type in US. Holttum (1985) suggested that it belonged in Tectaria, but there is an earlier homonym T. minima Underw.

$\wedge$ Ctenitis subglandulosa (Hance) Ching

Recorded for Fiji, together with a description, by Holttum (1985). DA 1745 in SUVA may be this species.

${ }^{\mathrm{E}} \wedge$ Ctenitis waiwaiensis (C.Chr.) Brownlie

The generic position of this species is unclear. It is known only from the type in K. Holttum (1985) suggested that it belongs in Dryoathyrium (= Deparia according to Smith et al. 2006), but it needs a new combination if transferred to Deparia. Brownlie (1977) thought its appearance was more suggestive of Hypolepis.

DRYOPTERIS Adans.

Dryopteris hasseltii (Blume) C.Chr.

Included under Arachniodes by Brownlie (1977) but now generally treated in Dryopteris (fide Parris et al. 1992).

$\wedge$ Dryopteris hirtipes (Blume) Kuntze

Specimens cited by Brownlie (1977), including Brownlie 911, 912 and 1814, are in CHR! (CHR 338837, 338833, 338836, respectively).

Dryopteris maxima (Baker) C.Chr.

Treated in Arachniodes by Brownlie (1977), but in Dryopteris by NMNS (2008). Very similar to Dryopteris arborescens (Baker) Kuntze from Samoa and the Solomon Islands (Christensen 1943; Glenny unpub.) and to D. subarborea (Christensen 1943, Brownlie 1977). It requires further investigation.

Dryopteris subarborea (Baker) C.Chr. 


\section{ELAPHOGLOSSUM Schott ex J.Sm.}

Elaphoglossum is in urgent need of revision in the Pacific. Seven new species were described by Krajina (1938) and another by Brownlie (1977), but they are poorly defined and need reinterpreting with modern techniques. Some are known only from the type, others are endemic to individual islands.

E Elaphoglossum basitruncatum Brownlie

E Elaphoglossum dominii Krajina

Elaphoglossum feejeense Brack.

Elaphoglossum gillespiei Copel.

E Elaphoglossum imthurnii Krajina

Elaphoglossum milnei Krajina

${ }^{\mathrm{A}} \wedge$ Elaphoglossum ovalauense Krajina

Known only from the type in $\mathrm{K}$.

\section{LASTREOPSIS Ching}

Lastreopsis davallioides (Brack.) Tindale

Lastreopsis tenera (R.Br.) Tindale

LOMAGRAMMA J.Sm.

Lomagramma cordipinna Holttum

Lomagramma polyphylla Brack.

POLYSTICHUM Roth.

Polystichum aff. moluccense (Blume) T.Moore (Fig. 1e)

Listed as P. aculeatum (L.) Roth by Brownlie (1977), but Parris (1994) and Glenny (unpub.) consider this species to be close to P. moluccense (Blume) T.Moore from the Moluccas, New Guinea and Solomon Islands. It also needs to be compared with material from Samoa (Christensen 1943).

E Polystichum pilosum Copel.

\section{LOMARIOPSIDACEAE}

Lomariopsidaceae, as construed by Smith et al. (2006), includes Lomariopsis and Nephrolepis, the latter previously included in the Davalliaceae by Brownlie (1977).

\section{LOMARIOPSIS Fée}

Lomariopsis brackenridgei Carruth.

Lomariopsis oleandrifolia (Brack.) Mett. in Kuhn

\section{NEPHROLEPIS Schott}

Nephrolepis biserrata (Sw.) Schott

Nephrolepis brownii (Desv.) Hovenkamp et Miyam.

Included within N. hirsutula by Brownlie (1977) but distinguished from that species by Hovenkamp \& Miyamoto (2005) who recognise both species in Fiji and provide good descriptions.

\section{Nephrolepis flexuosa Colenso}

Treated as N. tuberosa (Bory ex Willd.) C.Presl by Brownlie (1977), but described as N. cordifolia var. pseudolauterbachii by Hovenkamp \& Miyamoto (2005), based 
on a Fijian type. Distinguished as a separate species by de Lange et al. (2005), with a distribution including Norfolk Island, New Zealand and Fiji, and accepted at that rank here.

Nephrolepis hirsutula (G.Forst.) C.Presl

Nephrolepis obliterata (R.Br.) J.Sm.

Recognised as the endemic N. saligna Carruth. by Brownlie (1977), but treated by Hovenkamp \& Miyamoto (2005), and accepted here, as N. obliterata. Retained as N. saligna by NMNS (2008) although they also regard it as being in New Caledonia, Vanuatu, and Samoa.

\section{TECTARIACEAE}

Brownlie (1977) included Arthropteris in the Davalliaceae, and Pleocnemia and Tectaria in the Aspidiaceae. However, Smith et al. (2006) recognise them in the separate family Tectariaceae.

ARTHROPTERIS J.Sm. ex Hook.f.

Arthropteris articulata (Brack.) C.Chr.

$\wedge$ Arthropteris beckleri (Hook.) Mett.

Collected and recorded by NMNS (2008) (TNS 9523476). A description is provided by Bell (1998).

\section{Arthropteris repens (Brack.) C.Chr}

Holttum (1966) recognised both A. repens and A. palisotii (Desv.) Alston as present in Fiji, albeit doubtfully. Brownlie (1977) and NMNS (2008) accepted only A. repens, but Bell (1998) reduced $A$. repens to synonymy under $A$. palisotii. The latter is the correct name for the taxon if only one species is recognised.

PLEOCNEMIA C.Presl

Pleocnemia in Malesia has been revised by Holttum (1991).

Pleocnemia cumingiana C.Presl

$\wedge$ Pleocnemia elegans (Copel.) Holttum

Brownlie 1572, cited by Brownlie (1977), is in CHR (338869!).

Pleocnemia irregularis (C.Presl) Holttum

Pleocnemia leuzeana (Gaudich.) C.Presl

TECTARIA Cav.

Tectaria crenata Cav.

Tectaria decurrens (C.Presl) Copel.

Tectaria degeneri Copel.

$\wedge$ Tectaria dissecta (G.Forst.) Lellinger

Known only from specimens in BISH, US and TNS.

E Tectaria godeffroyi (Luerss.) Copel. (Fig. 1f)

Tectaria hookeri Brownlie

Described as T. hookerii by Brownlie (1977), but here corrected to T. hookeri. A specimen in SUVA, needing further investigation, has similar dissection to this species, but differs in its anastomosing veins, and polished red brown stipe. 
Tectaria latifolia (G.Forst.) Copel.

Tectaria menyanthidis (C.Presl) Copel.

${ }^{\mathrm{E}}$ Tectaria nausoriensis Brownlie

Tectaria tripartita (Baker) Copel.

${ }^{\mathrm{E}}$ Tectaria vitiensis Brownlie

\section{OLEANDRACEAE}

Oleandra was included within the Davalliaceae by Brownlie (1977), but is treated as a separate monogeneric family by Smith et al. (2006).

OLEANDRA Cav.

Oleandra neriiformis Cav.

Oleandra sibbaldii Grev.

$\wedge$ Oleandra whitmeei Baker

Included under O. sibbaldii by Brownlie (1977) but both are recorded, illustrated and distinguished by NMNS (2008) (TNS 9521031).

$\wedge$ Oleandra sp. 1

Collected, recorded and illustrated as an undescribed species by NMNS (2008) (TNS 9522051).

\section{DAVALLIACEAE}

Brownlie (1977) included several genera within his Davalliaceae, but Arthropteris, Leucostegia, Nephrolepis and Oleandra have now been transferred to Tectariaceae, Dryopteridaceae, Lomariopsidaceae and Oleandraceae, respectively (Smith et al. 2006). The remainder of Davalliaceae was revised by Kato \& Tsutsumi (2008), who recognised five genera, with three in Fiji (Davallia Sm., Humata Cav., and Wibelia Bernh.). However, Christenhusz et al. (2011) indicate problems with the treatment of Kato \& Tsutsumi (2008). These include an uncertain circumscription of Davallia sens. str. because the relationships of the type species have not been established, and the illegitimate adoption of Wibelia Bernh. when it is a later homonym of Wibelia G.Gaertn., B.Mey. et Scherb., a genus in the Asteraceae. Consequently, Christenhusz et al. (2011) advocate the recogniton of just two genera in the Davalliaceae, of which only Davallia occurs in Fiji. We follow this, but further investigation is clearly required.

DAVALLIA Sm.

Davallia epiphylla (G.Forst.) Spreng.

Reduced to synonymy with $D$. denticulata (Burm.f.) Mett. ex Kuhn by Nooteboom (1994). However, Glenny (unpub.) treats Fijian and Solomon Islands plants as $D$. epiphylla, distinct from $D$. denticulata, which he distinguishes as a closely related Malesian species lacking an acuminate lobe on the free margin of the indusium. Kato \& Tsutsumi (2008) treat both species in Wibelia but do not detail their distributions. However, reinstatement of this genus is illegitimate (Christenhusz et al. 2011).

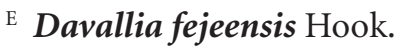

Treated as a variety of $D$. solida by Nooteboom (1994). Further work is needed to determine whether there is just one polymorphic taxon. 
Davallia heterophylla Sm.

Treated as Humata heterophylla (Sm.) Desv. by Brownlie (1977) and NMNS (2008).

Davallia pentaphylla Blume

Treated as Scyphularia pycnocarpa (Brack.) Copel. by Brownlie (1977) and NMNS (2008) but reduced to synonymy with $D$. pentaphylla by Nooteboom (1994). Kato \& Tsutsumi (2008) do not list D. pycnocarpa Brack.

\section{$\wedge$ Davallia plumosa Baker}

Recorded by NMNS (2008), but without citing a specimen, and distinguished from D. solida, which they also list for Fiji. Nooteboom (1994) reduces D. plumosa to synonymy with $D$. solida, but both are accepted by Kato \& Tsutsumi (2008). The $D$. solida complex requires further investigation.

Davallia botrychioides (Brack.) Baker

Treated as Humata botrychioides Brack. by Brownlie (1977) and NMNS (2008), but synonymised with D. repens (L.f.) Kuhn by Nooteboom (1994). However, Kato \& Tsutsumi (2008) recognise both species, under Humata (syn. H. repens (L.f.) Diels), but do not detail their distributions, and the relationship of these two species needs to be examined further.

\section{Davallia sessilifolia Blume}

Treated as Humata polypodioides by Brownlie (1977). Nooteboom (1994) synonymised this with Davallia sessilifolia. NMNS (2008) follow this synonymy, but place the species in Humata, as H. sessilifolia (Blume) Mett. However, Kato \& Tsutsumi (2008) recognise both species, under Humata, but do not detail their distributions, and the relationship of these species needs to be examined further. The combination in Davallia for Humata polypodioides is preoccupied.

Davallia solida (G.Forst.) Sw.

\section{POLYPODIACEAE}

Brownlie (1977) recognised Grammitis, Calymmodon and Ctenopteris in a separate Grammitidaceae, but the grammitid ferns nest within Polypodiaceae and we follow Smith et al. (2006) by including them in one family. Ctenopteris and Grammitis are polyphyletic (Ranker et al. 2004), and Parris (2007, 2010) has created combinations in the new genera Ctenopterella, Dasygrammitis, Oreogrammitis, Radiogrammitis, and Tomophyllum for the Fijian species. Brownlie also included Dipteris in the Polypodiaceae but we follow Smith et al. (2006) by placing it in a separate family, Dipteridaceae.

AGLAOMORPHA Schott

$\wedge$ Aglaomorpha drynarioides (Hook.) M.C.Roos

Included in Merinthosorus by Brownlie (1977) but reduced to synonymy in Aglaomorpha by Roos (1986). Known only from a single specimen in BISH from Cakaudrove.

\section{BELVISIA Mirb.}

Belvisia melanesica Brownlie

Described by Brownlie (1977) from Fiji but reduced to synonymy under $B$. mucronata by Hovenkamp \& Franken (1993), although they did not see the type. However, Parris (1994) records it growing with B. mucronata on Taveuni, and it is accepted here. 
Belvisia mucronata (Fée) Copel.

$\wedge$ Belvisia spicata (L.f.) Mirb. ex Copel.

Recorded for Fiji by Hovenkamp \& Franken (1993) and Glenny (unpub.). A description is given by Hovenkamp \& Franken (1993).

CALYMMODON C.Presl

Calymmodon latealatus Copel.

CTENOPTERELLA Parris

Ctenopterella blechnoides (Grev.) Parris

Treated in Ctenopteris by Brownlie (1977).

E Ctenopterella seemannii (J.Sm.) Parris

Treated in Ctenopteris by Brownlie (1977).

$\wedge$ Ctenopterella vodonaivalui (Brownlie) Parris

Described by Brownlie (1977) in Ctenopteris.

DASYGRAMMITIS Parris

Dasygrammitis crassifrons (Baker) Parris

Treated in Ctenopteris by Brownlie (1977).

DICTYMIA J.Sm.

Dictymia mckeei Tindale

DRYNARIA (Bory) J.Sm.

Drynaria rigidula (Sw.) Bedd.

GONIOPHLEBIUM (Blume) C.Presl

$\wedge$ Goniophlebium persicifolium (Desv.) Bedd.

Collected and recorded by NMNS (2008) (TNS 9520083). A description is given by Hovenkamp et al. (1998).

\section{Goniophlebium serratifolium Brack.}

Recorded as Polypodium subauriculatum Blume by Brownlie (1977) but included in Goniophlebium by Hovenkamp et al. (1998). They list G. serratifolium for Fiji rather than G. subauriculatum (Blume) C.Presl with which it has been confused.

GRAMMITIS Sw.

Grammitis vaupelii (Brause) Copel.

OREOGRAMMITIS Copel.

$\wedge$ Oreogrammitis adspersa (Blume) Parris

Recorded for Fiji as Grammitis adspersa (Blume) Blume by Parris (1983), and later transferred to Oreogrammitis (Parris 2007). A description is given by Parris (1983).

$\mathrm{E} \wedge$ Oreogrammitis alta (Parris) Parris

Described by Brownlie (1977) as G. stipitata, but this is a later homonym of G. stipitata Proctor. Parris (1980) proposed G. alta as a nomen novum for this species, but it has now been transferred to Oreogrammitis. Known only from the holotype in CHR (338806!). 
Oreogrammitis conformis (Brack.) Parris

Treated in Grammitis by Brownlie (1977).

E Oreogrammitis glabrata (Brownlie) Parris

Described by Brownlie (1977) in Grammitis. Known only from the type in SUVA and CHR (338804!).

Oreogrammitis knutsfordiana (Baker) Parris

Treated as Grammitis hookeri (Brack.) Copel. by Brownlie (1977) and NMNS (2008), but Fijian material is now included under O. knutsfordiana (Barbara Parris pers. comm., 7 April 2008).

Oreogrammitis pleurogrammoides (Rosenst.) Parris

Described by Brownlie (1977) as Grammitis vitiensis, but reduced to synonymy under O. pleurogrammoides by Parris (2007)

\section{LEMMAPHYLLUM C.Presl}

Lemmaphyllum accedens (Blume) Donk

LOXOGRAMME (Blume) C.Presl

Loxogramme parksii Copel.

\section{MICROSORUM Link}

The genus was listed as Microsorium by Brownlie (1977) but is correctly spelt Microsorum. Brownlie recognised both Microsorum and Phymatosorus, but we follow Nooteboom (1997) in accepting only the former.

E Microsorum alatum (Brack.) Copel.

Microsorum commutatum (Blume) Copel.

Recorded as M. vitiense (Baker) Copel. by Brownlie (1977) but reduced to synonymy under M. commutatum by Nooteboom (1997). NMNS treat the latter as Phymatosorus commutatus (Blume) Pic.Serm. but erroneously describe it as endemic to Fiji.

Microsorum grossum (Langsd. et Fisch.) S.B.Andrews

Recorded as Phymatosorus grossus (Langsd. et Fisch.) Brownlie by Brownlie (1977), but reduced to synonymy under Microsorum scolopendria by Nooteboom (1997). However, we follow Murdock \& Smith (2003) and Bostock \& Spokes (1998b) in retaining both species.

Microsorum linguiforme (Mett.) Copel.

Listed as M. linguaeforme by Brownlie (1977) but correctly spelt M. linguiforme (Nooteboom 1997).

Microsorum membranifolium (R.Br.) Ching

Recorded as Phymatosorus nigrescens (Blume) Pic.Serm. by Brownlie (1977), but reduced to synonymy under Microsorum membranifolium by Nooteboom (1997). NMNS (2008) treat the latter as Phymatosorus membranifolius (R.Br.) S.G.Lu.

E Microsorum parksii (Copel.) Copel.

Recognised in Phymatosorus by Brownlie (1977) but included in Microsorum by Nooteboom (1997). 
Microsorum punctatum (L.) Copel.

Microsorum scolopendria (Burm.f.) Copel.

Recognised in Phymatosorus by Brownlie (1977) but included in Microsorum by Nooteboom (1997).

PROSAPTIA C.Presl

Prosaptia contigua (G.Forst.) C.Presl

Treated in Ctenopteris by Brownlie (1977).

${ }^{\mathrm{A}} \wedge$ Prosaptia immersa (Brownlie) Parris

Described by Brownlie (1977) in Ctenopteris. Known only from the holotype in CHR (338887!).

Prosaptia vomaensis (Brownlie) Parris

Described by Brownlie (1977) in Ctenopteris.

\section{PYRROSIA Mirb.}

Pyrrosia lanceolata (L.) Farw.

Recognised as P. adnascens (Sw.) Ching by Brownlie (1977) but reduced to synonymy under the widespread P. lanceolata by Hovenkamp (1986).

Pyrrosia serpens (G.Forst.) Ching

Recognised as P. blepharolepis (C.Chr.) Ching by Brownlie (1977) but reduced to synonymy under the Polynesian species $P$. serpens by Hovenkamp (1986).

RADIOGRAMMITIS Parris

Radiogrammitis hirtelloides (Copel.) Parris

Treated in Grammitis by Brownlie (1977).

SELLIGUEA Bory

Selliguea feeioides Copel.

TOMOPHYLLUM (E.Fourn.) Parris

E Tomophyllum hornei (Baker) Parris

Treated in Ctenopteris by Brownlie (1977).

\section{Acknowledgments}

This work was carried out by the authors as a subcontract between Landcare Research New Zealand Ltd (Client) and Te Papa (Consultant) in June 2008. The subcontract formed part of the project 'Plant reference collections and molecular-level systematics for biodiversity and biosecurity in the South Pacific' a Ministry of Research Science and Technology project funded by the New Zealand Overseas Development Agency Contestable Fund (New Zealand Aid Programme). It will contribute to capacity building in the South Pacific Regional Herbarium (SUVA) at the University of the South Pacific, Suva, Fiji.

We would like thank Grant Hunter at Landcare Research for negotiating this subcontract with Te Papa. We are also extremely grateful to Marika Tuiwawa, Alvereti Naikatini and the staff of the South Pacific Regional Herbarium for their generous hospitality in Suva, for providing excellent working space, for making the facilities of the herbarium available to us after hours, and for discussions on the Checklist presented here. 
We are also grateful to David Glenny, Barbara Parris and Bill Sykes for discussions on the correct nomenclature for Pacific ferns, based on ther knowledge of the ferns of Malesia and the Pacific region.

\section{References}

Ballard, F. (1955) Ferns and fern allies: miscellaneous notes. Kew Bulletin 1954: 559-561.

Bell GH (1998) Davalliaceae. Flora of Australia 48: 434-450.

Bostock PD (1998a) Adiantaceae. Flora of Australia 48: 248-286.

Bostock PD (1998b) Thelypteridaceae. Flora of Australia 48: 327-358.

Bostock PD \& Spokes TM (1998a) Hymenophyllaceae. Flora of Australia 48: 116-148.

Bostock PD \& Spokes TM (1998b) Polypodiaceae. Flora of Australia 48: 468-495.

Brownlie G (1977) The pteridophyte flora of Fiji. (Cramer: Vaduz)

Brownsey PJ (1987) A review of the fern genus Hypolepis (Dennstaedtiaceae) in the Malesian and Pacific regions. Blumea 32: 227-276.

Brownsey PJ (2001) New Zealand's pteridophyte flora - plants of ancient lineage but recent arrival? Brittonia 53: 284-303.

Brownsey PJ \& Perrie LR (2008) Updating Fijian fern names. Landcare Research IBG Report: LC0708/168 (unpublished). (Manaaki Whenua - Landcare Research: Christchurch, New Zealand)

Chambers TC \& Farrant PA (1998) Cheilanthes. Flora of Australia 48: 271-286.

Chambers TC \& Farrant PA (2001) Revision of Blechnum (Blechnaceae) in Malesia. Blumea 46: 283-350.

Chinnock RJ (1998a) Lycopodiaceae. Flora of Australia 48: 66-85.

Chinnock RJ (1998b) Psilotaceae. Flora of Australia 48: 47-53.

Chinnock RJ (1998c) Lygodiaceae. Flora of Australia 48: 183-187.

Christenhusz MJ, Xian-Chun Z, Schneider H (2011) A linear sequence of extant families and genera of lycophytes and ferns. Phytotaxa 19: 7-54.

Christensen C (1906) Index filicum. (Hagerup: Copenhagen)

Christensen C (1943) A revision of the Pteridophyta of Samoa. B.P. Bishop Museum Bulletin 177: $1-138$.

Copeland EB (1929) Ferns of Fiji. B.P. Bishop Museum Bulletin 59: 1-105.

Copeland EB (1937) Hymenophyllum. Philippine Journal of Science 64: 1-188.

de Lange PJ, Gardner RO, Sykes WR, Crowcroft GM, Cameron EK, Stalker F, Christian M \& Braggins JE (2005) Vascular flora of Norfolk Island; some additions and and taxonomic notes. New Zealand Journal of Botany 43: 563-596.

Ebihara A \& Iwatsuki K (2007) The Hymenophyllaceae of the Pacific Area. 1. Hymenophyllum subgenus Hymenophyllum. Bulletin of the National Museum of Natural Sciences, Series B 33: $55-68$.

Ebihara A, Dubuisson J-Y, Iwatsuki K, Hennequin S \& Ito M (2006) A taxonomic revision of Hymenophyllaceae. Blumea 51:221-280.

Gardner RO (1997) A concise account of Selaginella in Fiji. New Zealand Journal of Botany 35: 269-281.

Glenny D Ferns of the Solomon Islands. Unpublished manuscript, Te Papa, Wellington, New Zealand.

Hauke R (1963) A taxonomic monograph of the genus Equisetum subgenus Hippochaete. Beihefte zur Nova Hedwigia 8: 1-123.

Hennipman E (1977) A monograph of the fern genus Bolbitis (Lomariopsidaceae). Leiden Botanical Series 2: 1-331.

Holttum RE (1959) Gleicheniaceae. Flora Malesiana, Series II, 1: 1-36.

Holttum RE (1966) The genus Arthropteris J.Sm. in Malesia. Blumea 14: 225-229.

Holttum RE (1968) A re-definition of the fern genus Taenitis. Blumea 16: 87-95. 
Holttum RE (1971) Studies in the family Thelypteridaceae III. A new system of genera in the Old World. Blumea 19: 17-52.

Holttum RE (1975) Studies in the family Thelypteridaceae VIII. The genera Mesophlebion and Plesioneuron. Blumea 22: 223-250.

Holttum RE (1977) The family Thelypteridaceae in the Pacific and Australasia. Allertonia 1: $169-234$.

Holttum RE (1981) Thelypteridaceae. Flora Malesiana, Series II, 1: 331-599.

Holttum RE (1985) Studies in the fern genera allied to Tectaria Cav. IV. The genus Ctenitis in Asia, Malesia and the Western Pacific. Blumea 31: 1-38.

Holttum RE (1991) Tectaria group. Flora Malesiana, Series II, 2: 1-132.

Hovenkamp PH (1986) A monograph of the fern genus Pyrrosia (Polypodiaceae). Leiden Botanical Series 9: 1-280.

Hovenkamp PH, Saunders RMK, Lafferriere JE, Kato M, Zhang X \& Nooteboom HP (1998) Polypodiaceae. Flora Malesiana, Series II, 3: 1-234.

Hovenkamp PH \& Franken NAP (1993) An account of the fern genus Belvisia Mirbel (Polypodiaceae). Blumea 37: 511-527.

Hovenkamp PH \& Miyamoto F (2005) A conspectus of the native and naturalized species of Nephrolepis (Nephrolepidaceae) in the world. Blumea 50: 279-322.

Jermy AC \& Holmes JS (1998) Selaginellaceae. Flora of Australia 48: 85-95.

Jones DL (1998a) Athyriaceae. Flora of Australia 48: 418-429.

Jones DL (1998b) Lomariopsidaceae. Flora of Australia 48: 429-434.

Jones DL (1998c) Vittariaceae. Flora of Australia 48: 288-295.

Kato M (1984) A taxonomic study of the athyrioid fern genus Deparia with main reference to the Pacific species. Journal of the Faculty of Science, University of Tokyo, sect. III, 13: 375-429.

Kato M (1988) Taenitis and allied genera of Ambon and Seram (Moluccas) and notes on taxonomic and phytogeographic relationships of Taenitis. Journal of the Faculty of Science, University of Tokyo, sect. III, 14: 161-182.

Kato M \& Tsutsumi C (2008) Generic classification of Davalliaceae. Acta Phytotaxonomica et Geobotanica 59: 1-14.

Krajina V (1938) Seven new Polynesian species of Elaphoglossum from the group E. conforme (Sw.) Schott. Studia botanica Čechoslovaca 1: 61-70.

Kramer KU (1970) The lindsaeoid ferns of the Old World V. The smaller Pacific islands. Blumea 18: 157-194.

Kramer KU \& McCarthy PM (1998) Pteridaceae. Flora of Australia 48: 241-248.

Kramer KU \& Zogg E (1988) Pseudophegopteris (Thelypteridaceae) in Fiji, a new record and a new species. Blumea 33: 423-426.

Large MF \& Braggins JE (2004) Tree ferns. (CSIRO Publishing: Melbourne)

Lehtonen S, Tuomisto H, Rouhan G, Christenhusz MJM (2010) Phylogenetics and classification of the pantropical fern family Lindsaeaceae. Botanical Journal of the Linnean Society 163: 305-359.

Li H-L , Liu T-S, Huang T-C, Koyama T \& DeVol CE (1975) Flora of Taiwan . I. Pteridophyta and Gymnospermae. (Epoch Publishing Co.: Taipei)

Maxon WR (1922) The genus Culcita. Journal of the Washington Academy of Sciences 12: 454-460.

Mickel JT \& Smith AR (2004) The pteridophytes of Mexico. Memoirs of the New York Botanical Garden 188: 1-1054.

Mitchell DS (1972) The Kariba weed: Salvinia molesta. British Fern Gazette 10: 251-252.

Murdock AG \& Smith AR (2003) Pteridophytes of Moorea, French Polynesia, with a new species, Tmesipteris gracilis (Psilotaceae). Pacific Science 57: 253-265.

National Museum of Nature and Science (eds) (2008) Illustrated Flora of ferns and fern allies of South Pacific islands. National Museum of Nature and Science Book Series No. 8. (Tokai University Press: Tokyo)

Nooteboom HP (1994) Notes on Davalliaceae II. A revision of the genus Davallia. Blumea 39: 151-214. 
Nooteboom HP (1997) The microsoroid ferns (Polypodiaceae). Blumea 42: 261-395.

Øllgard B (1987) A revised classification of the Lycopodiaceae sens. lat. Opera Botanica 92: 153178.

Parris BS (1980) Further notes on Doodia, Grammitis and Blechnum. New Zealand Journal of Botany 18: 145-147.

Parris BS (1983) A taxonomic revision of the genus Grammitis Swartz (Grammitidaceae: Filicales) in New Guinea. Blumea 29: 13-222.

Parris BS (1994) Additions to the pteridophyte flora of Taveuni, Fiji. Fern Gazette 14: 255-258.

Parris BS (1998) Doodia. Flora of Australia 48: 385-393.

Parris BS (2007) Five new genera and three new species of Grammitidaceae (Filicales) and the re-establishment of Oreogrammitis. Gardens' Bulletin Singapore 58: 233-274.

Parris BS (2010) New combinations in Oreogrammitis, Prosaptia, Radiogrammitis, Themelium and Tomophyllum (Grammitidaceae: Polypodiopsida: Monilophyta) from Malesia and the Pacific Islands. Kew Bulletin 65: 123-125.

Parris BS, Beaman RS \& Beaman JH (1992) The plants of Mount Kinabalu. I. Ferns and fern allies. (Royal Botanic Gardens: Kew)

Pichi Sermolli REG (1991) The pteridological collections of the G.R.S.T.S. Expedition to the coastal region of north-eastern Queensland. Webbia 45: 317-379.

Ranker TA, Smith AR, Parris BS, Geiger JMO, Haufler CH, Straub SCK \& Schneider H (2004) Phylogeny and evolution of the grammitid ferns (Grammitidaceae): a case of rampant morphological homoplasy. Taxon 53: 415-428.

Roos MC (1986) Phylogenetic systematics of the Drynarioideae (Polypodiaceae). Verhandelingen van de Koninklijke Nederlandse Akademie van Wetenschappen, Afd. Natuurkunde, Tweed Reeks 85: $1-318$.

Schuettpelz E \& Pryer KM (2007) Fern phylogeny inferred from 400 leptosporangiate species and three plastid genes. Taxon 56: 1037-1050.

Shepherd LD, Perrie LR, Parris BS \& Brownsey PJ (2007) A molecular phylogeny for the New Zealand Blechnaceae ferns from analyses of chloroplast trnL-trnF DNA sequences. New Zealand Journal of Botany 45: 67-80.

Smith AR, Pryer KM, Schuettpelz E, Korall P, Schneider H \& Wolf PG ( 2006) A classification for extant ferns. Taxon 55: 705-731.

Thiers B (2011) Index Herbariorum: A global directory of public herbaria and associated staff. New York Botanical Garden's Virtual Herbarium. http://sweetgum.nybg.org/ih/

White RA \& Turner MD (1988) Calochlaena, a new genus of dicksonioid ferns. American Fern Journal 78: 86-95.

Yoroi R \& Iwatsuki K (1977) An observation on the variation of Trichomanes minutum and allied species. Acta Phytotaxonomica Geobotanica 28: 152-159.

Manuscript received 23 November 2010, accepted 20 July 2011 

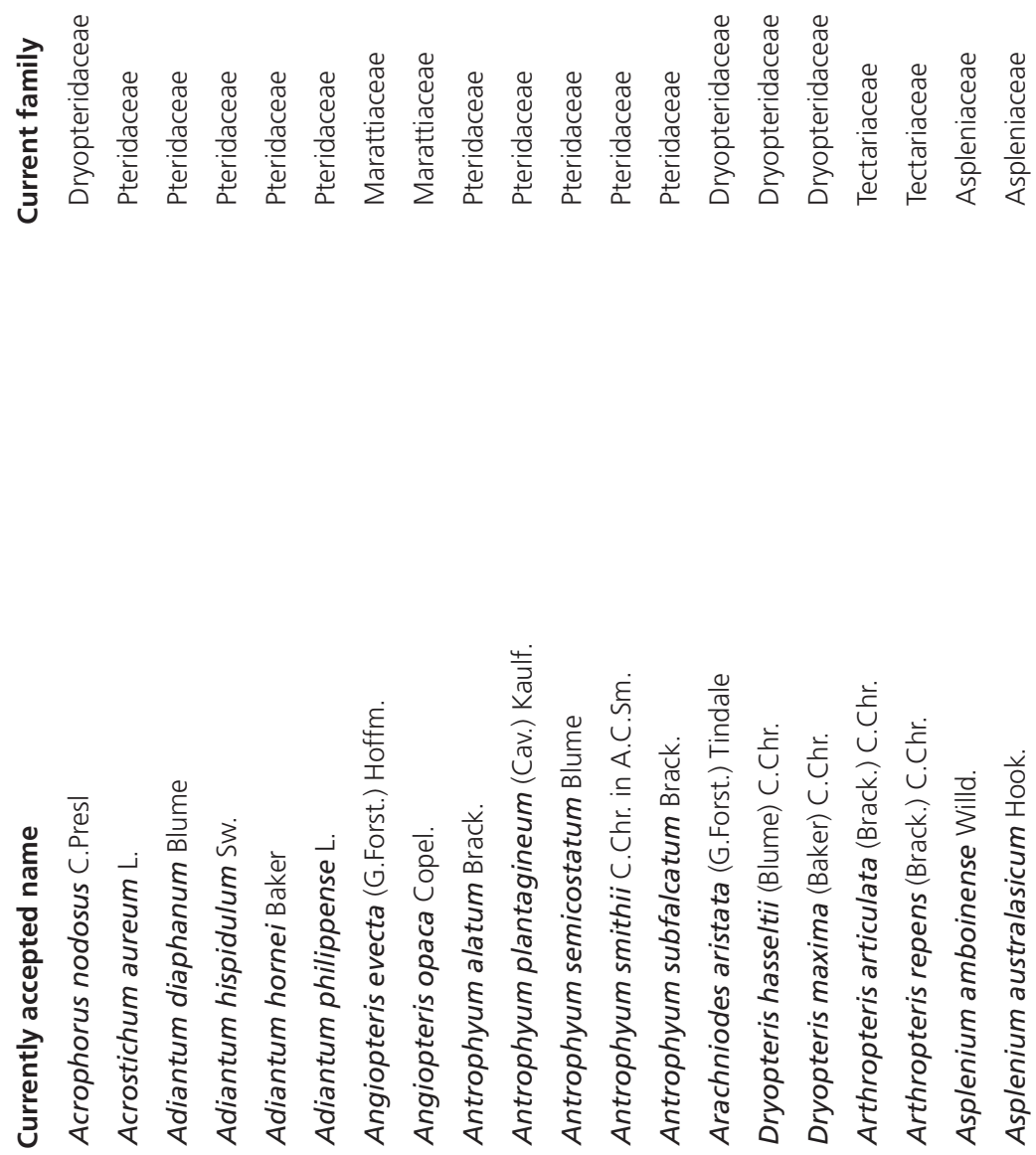

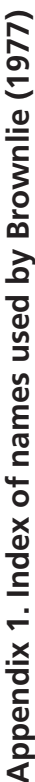

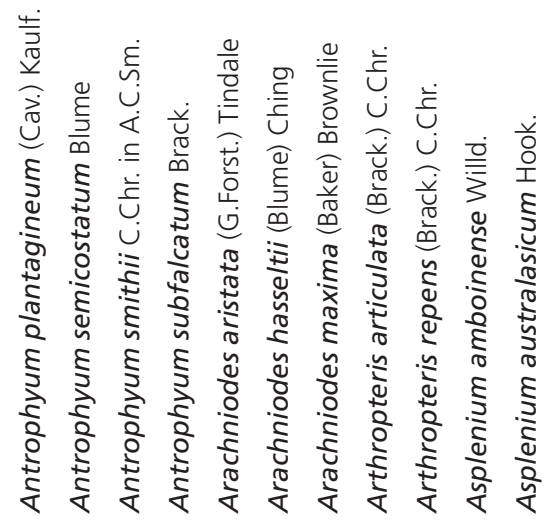



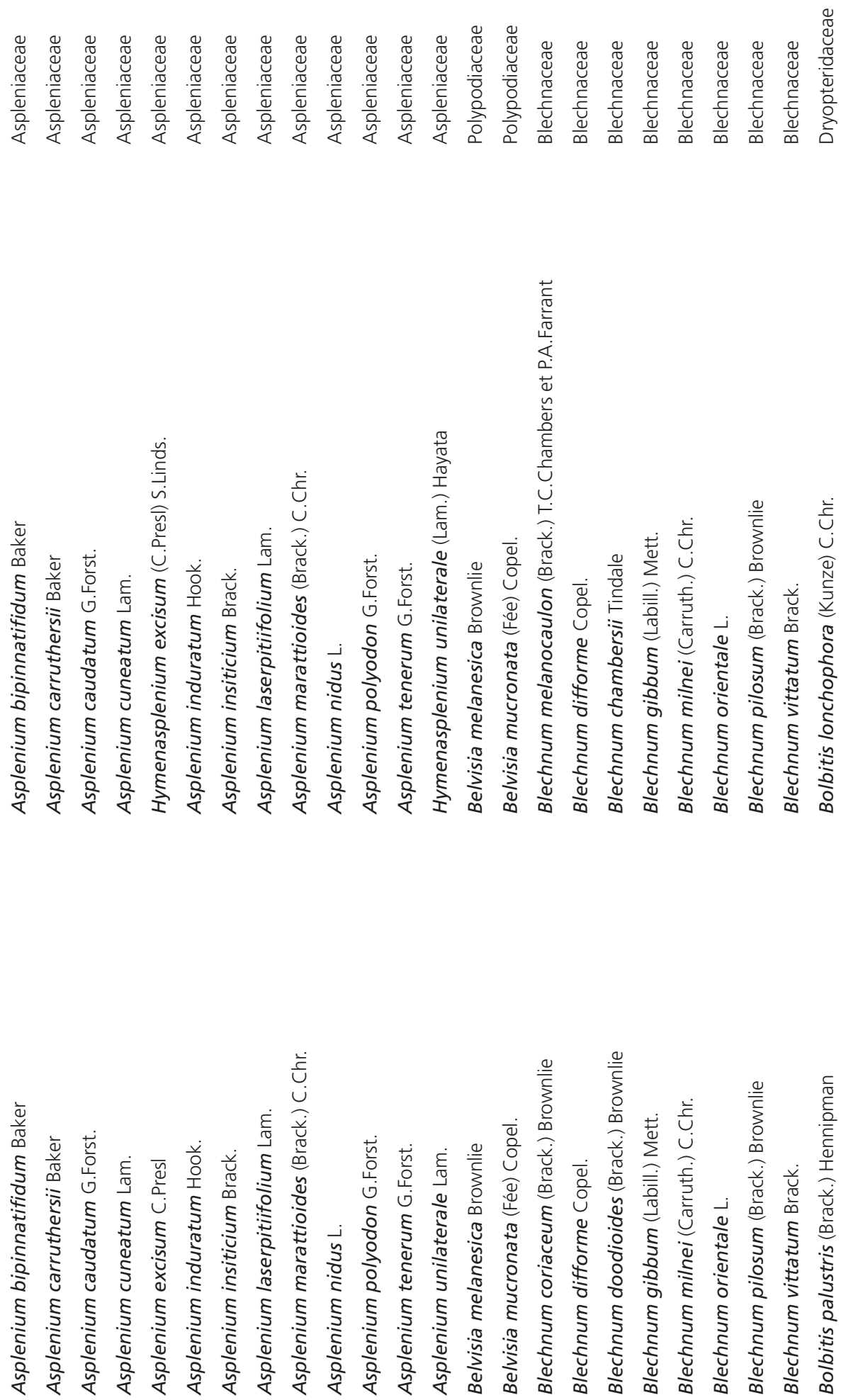

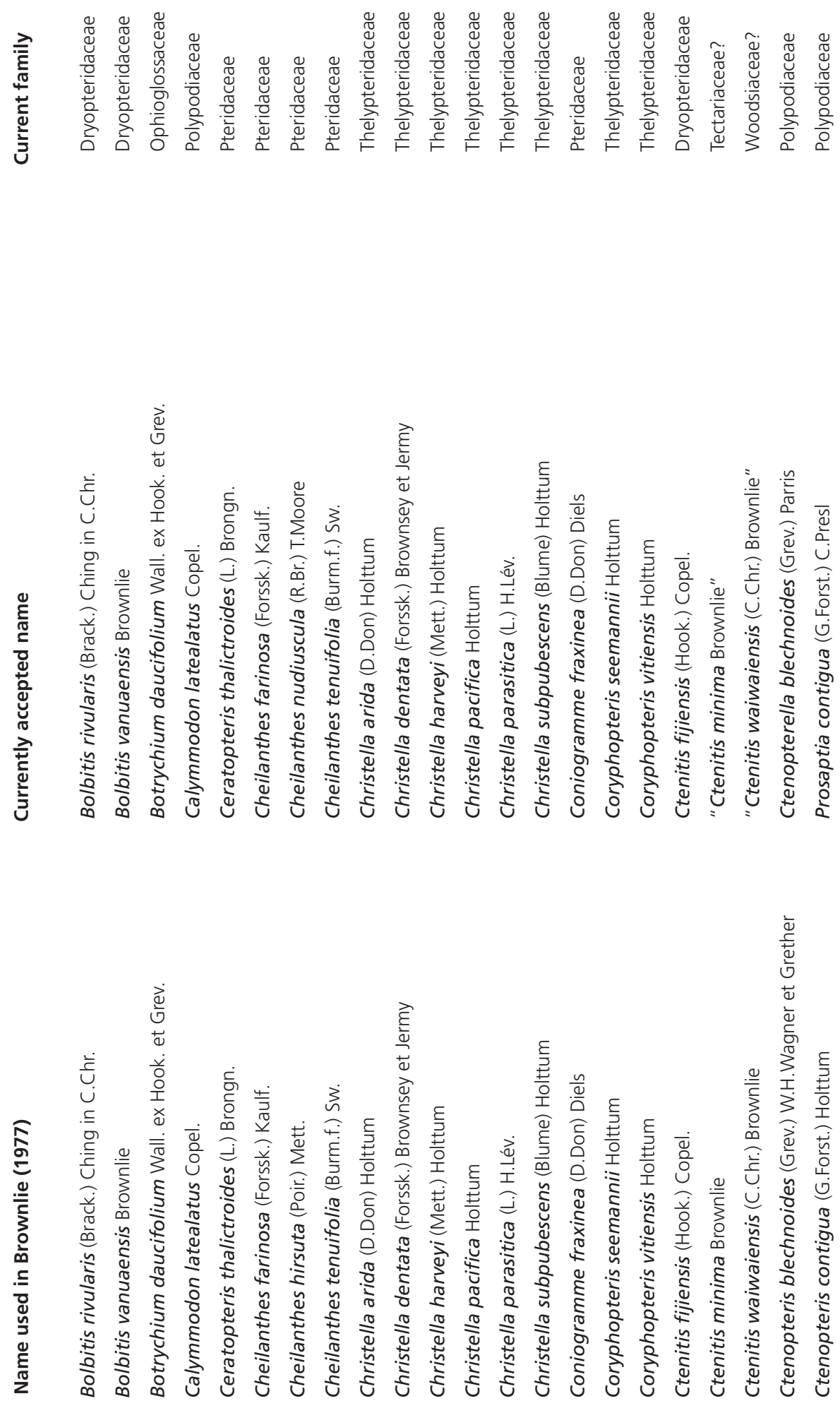

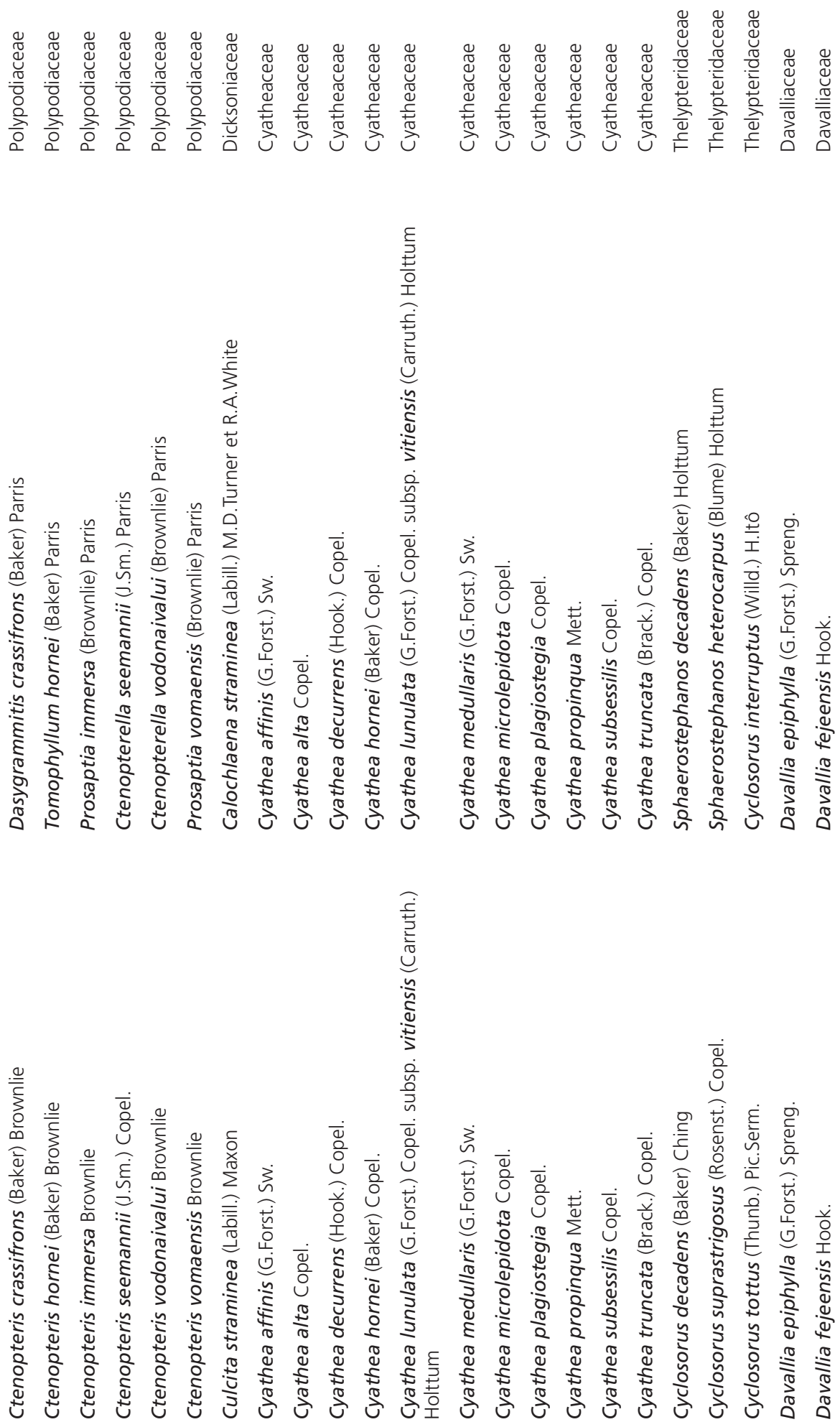

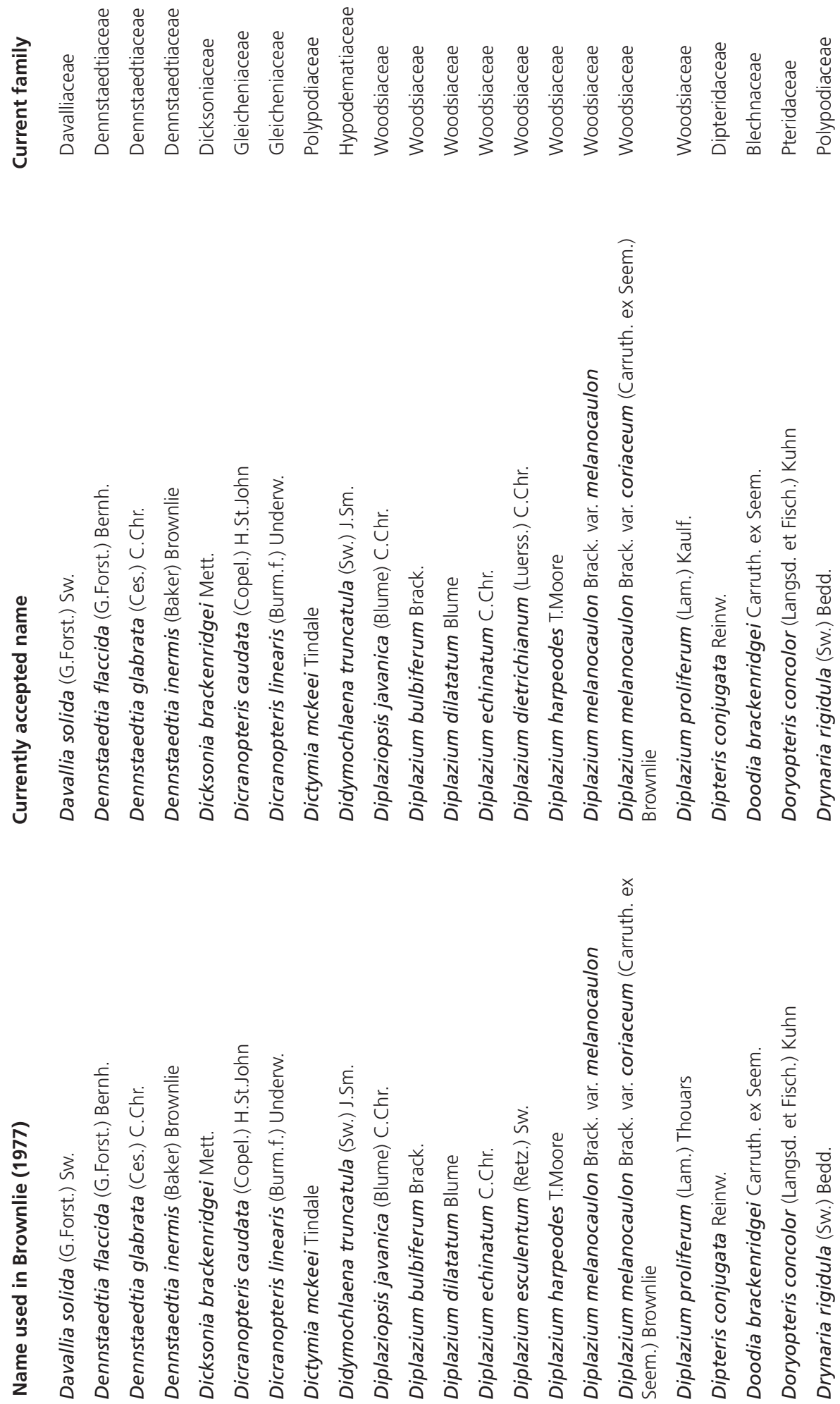

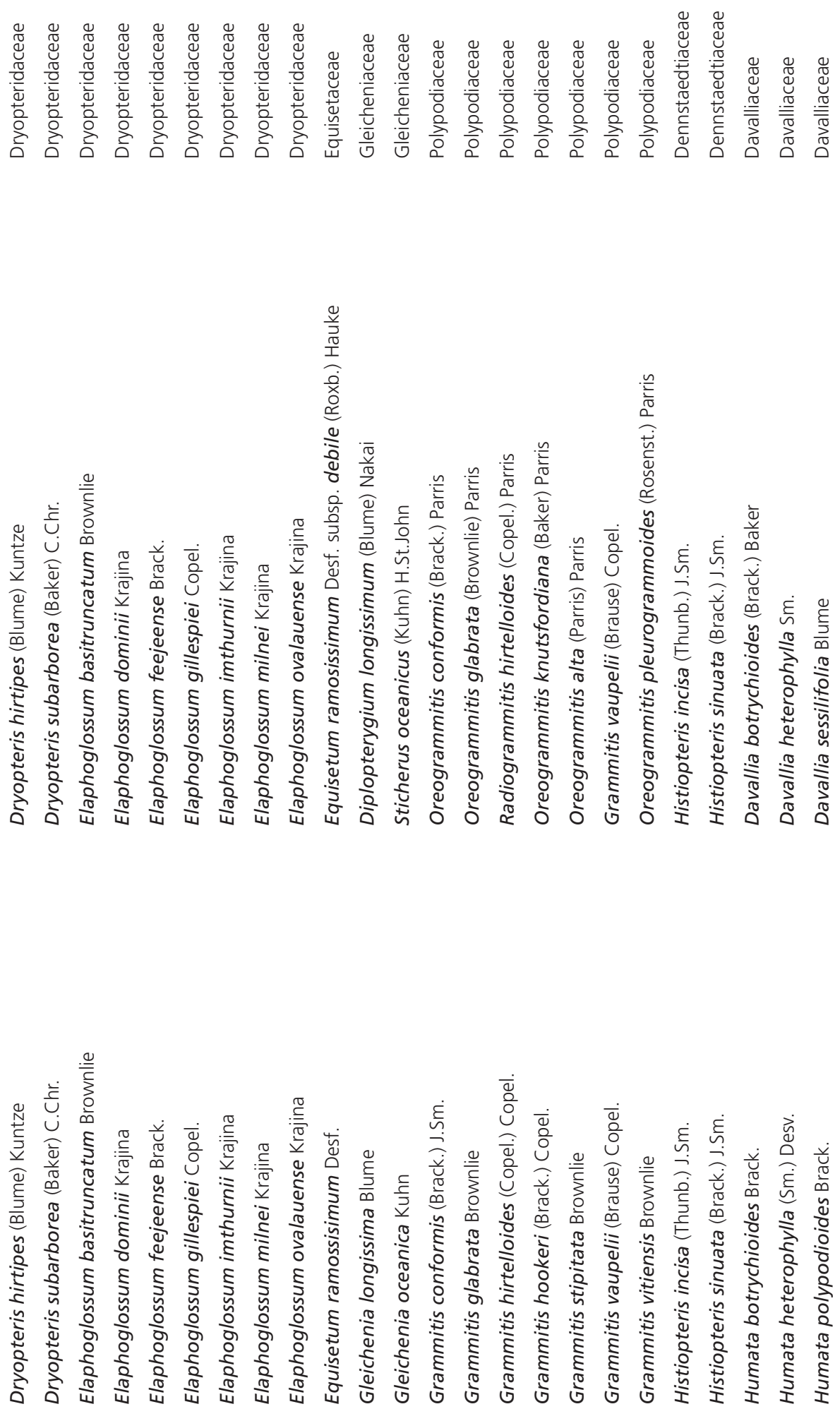

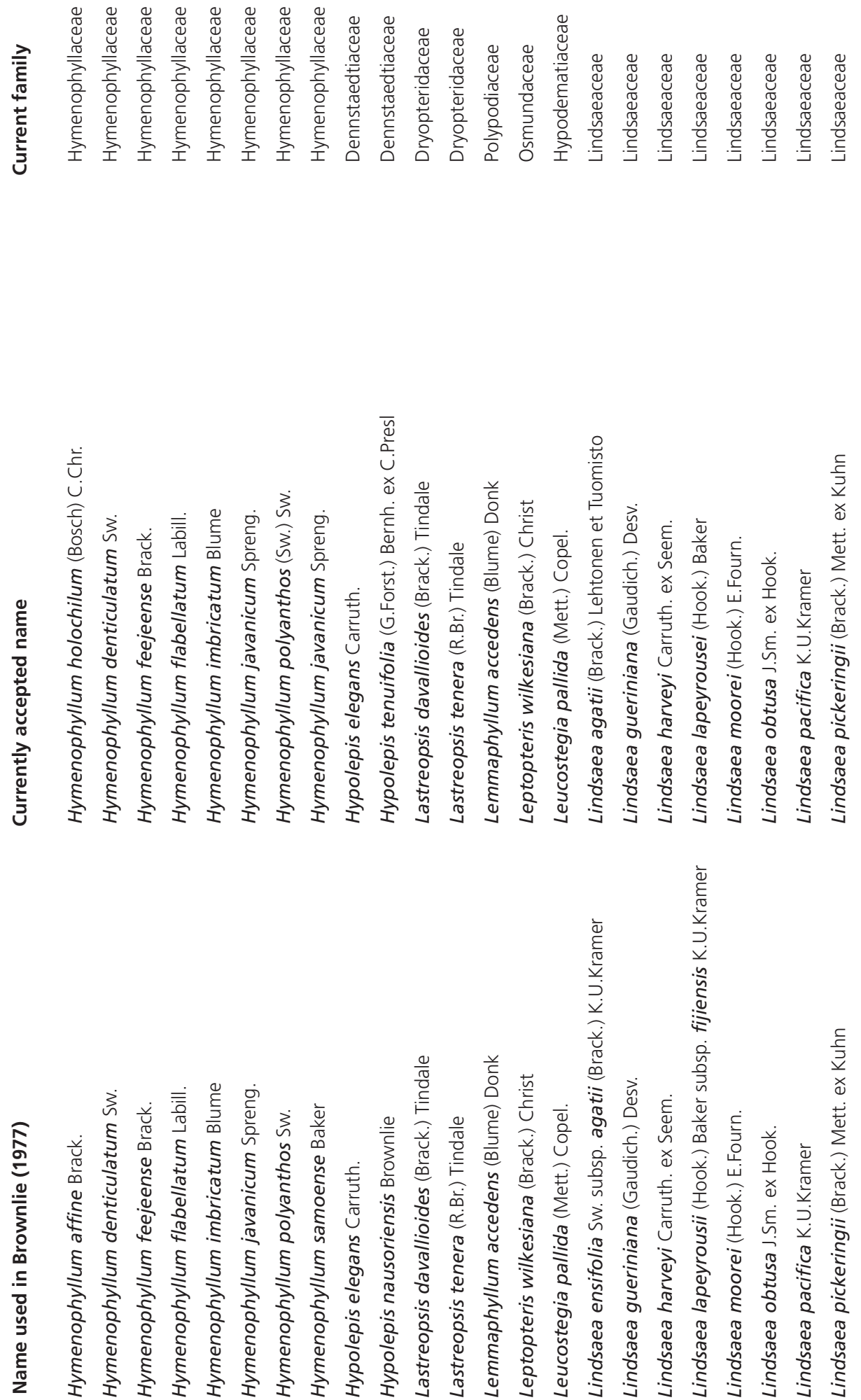

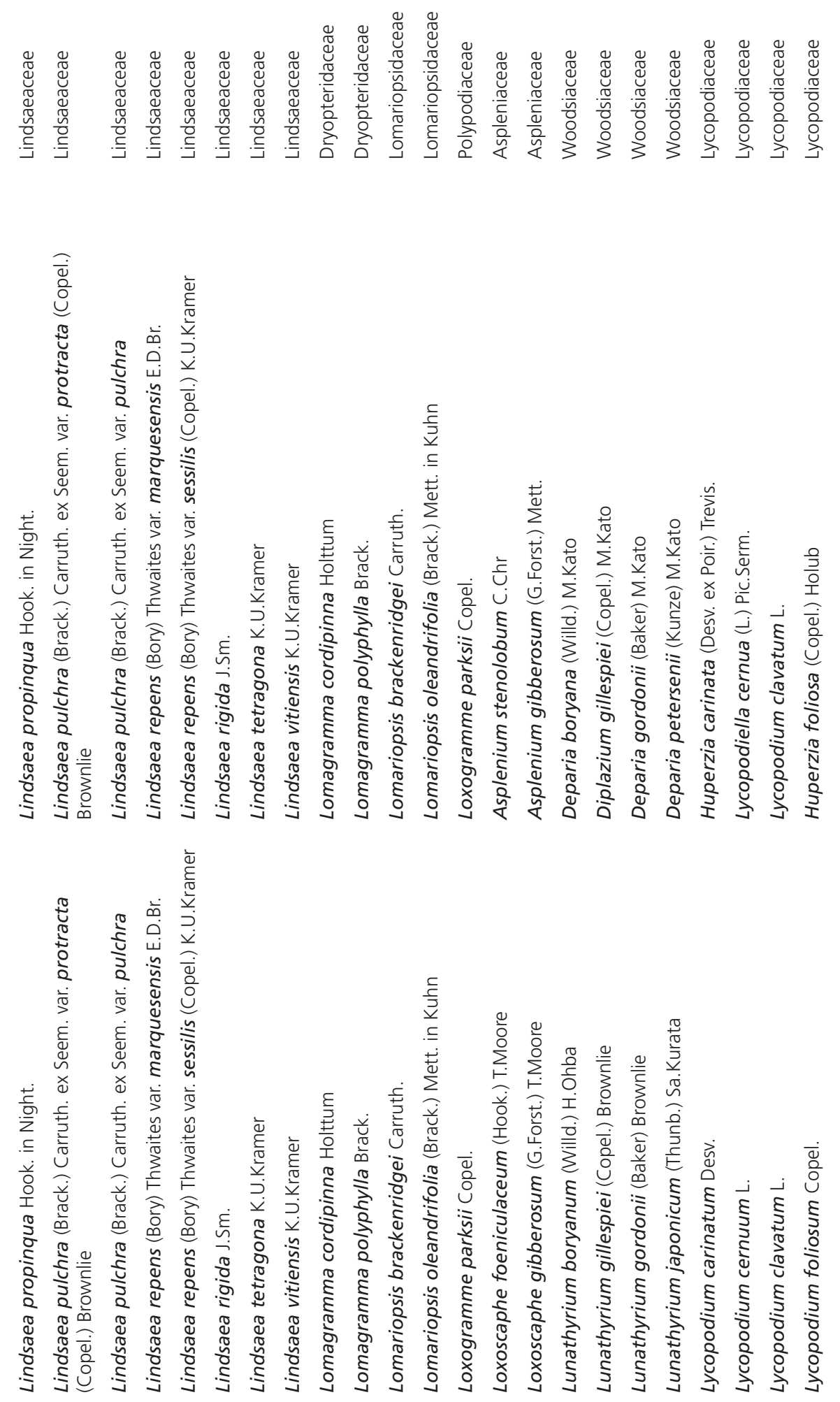

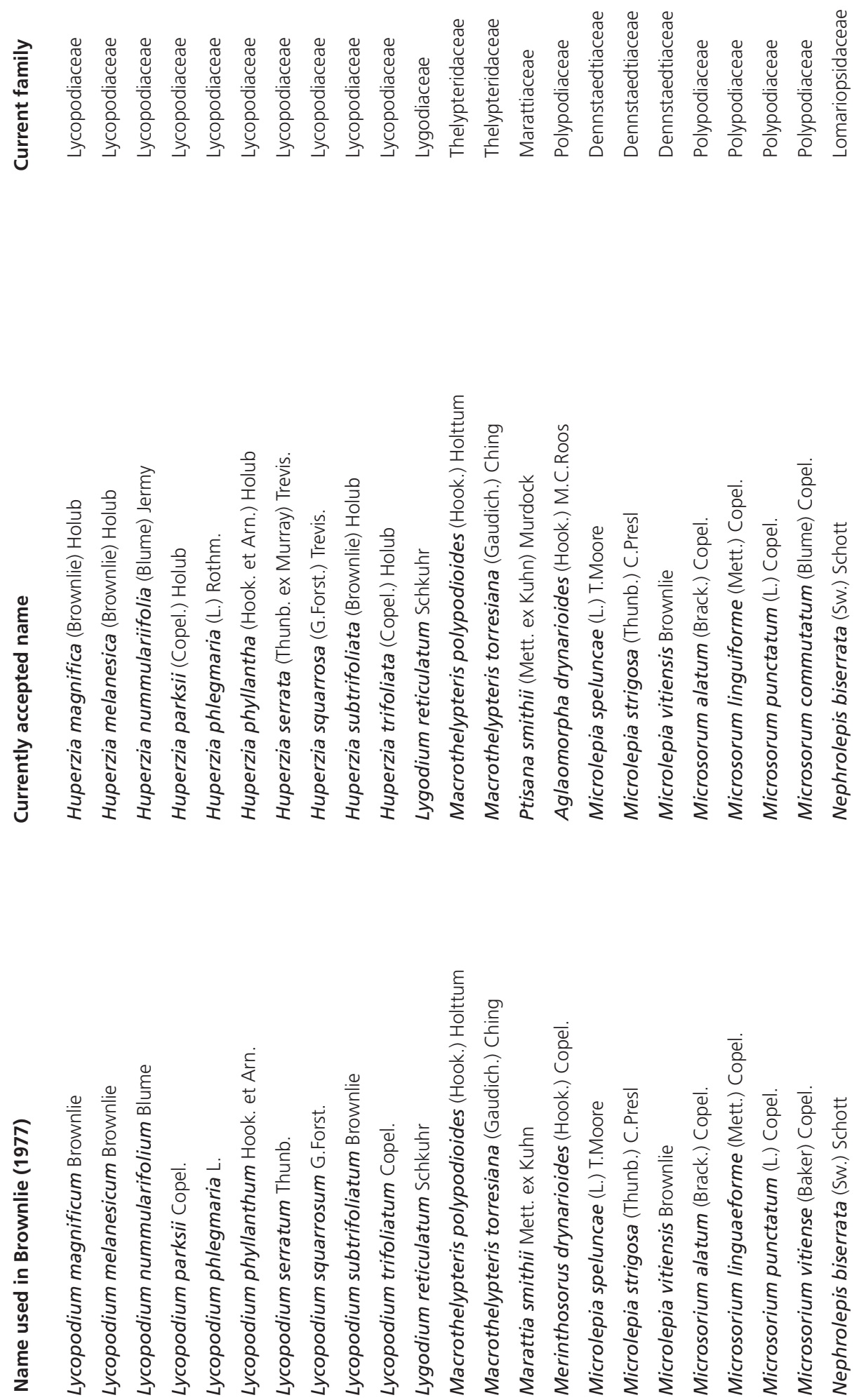

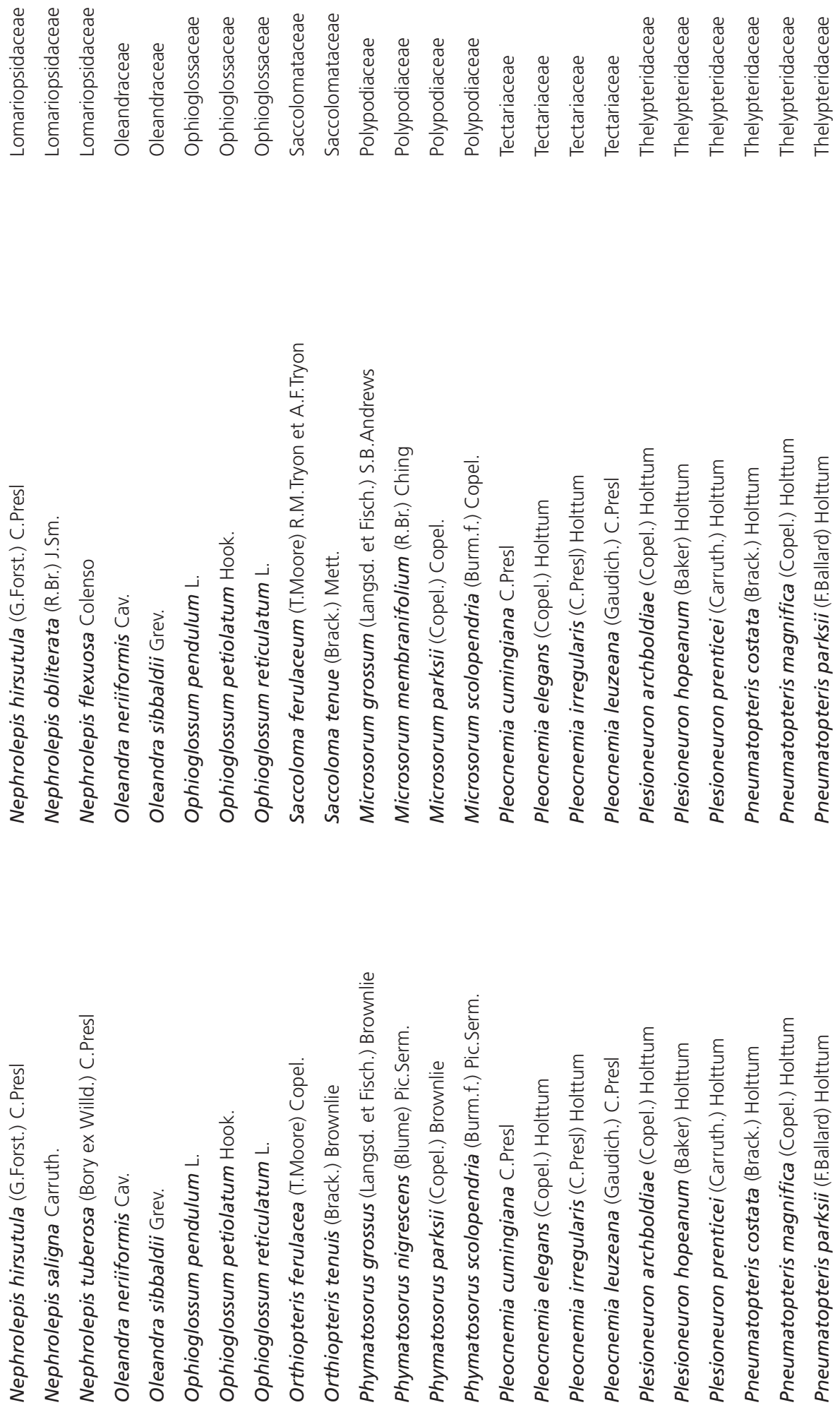

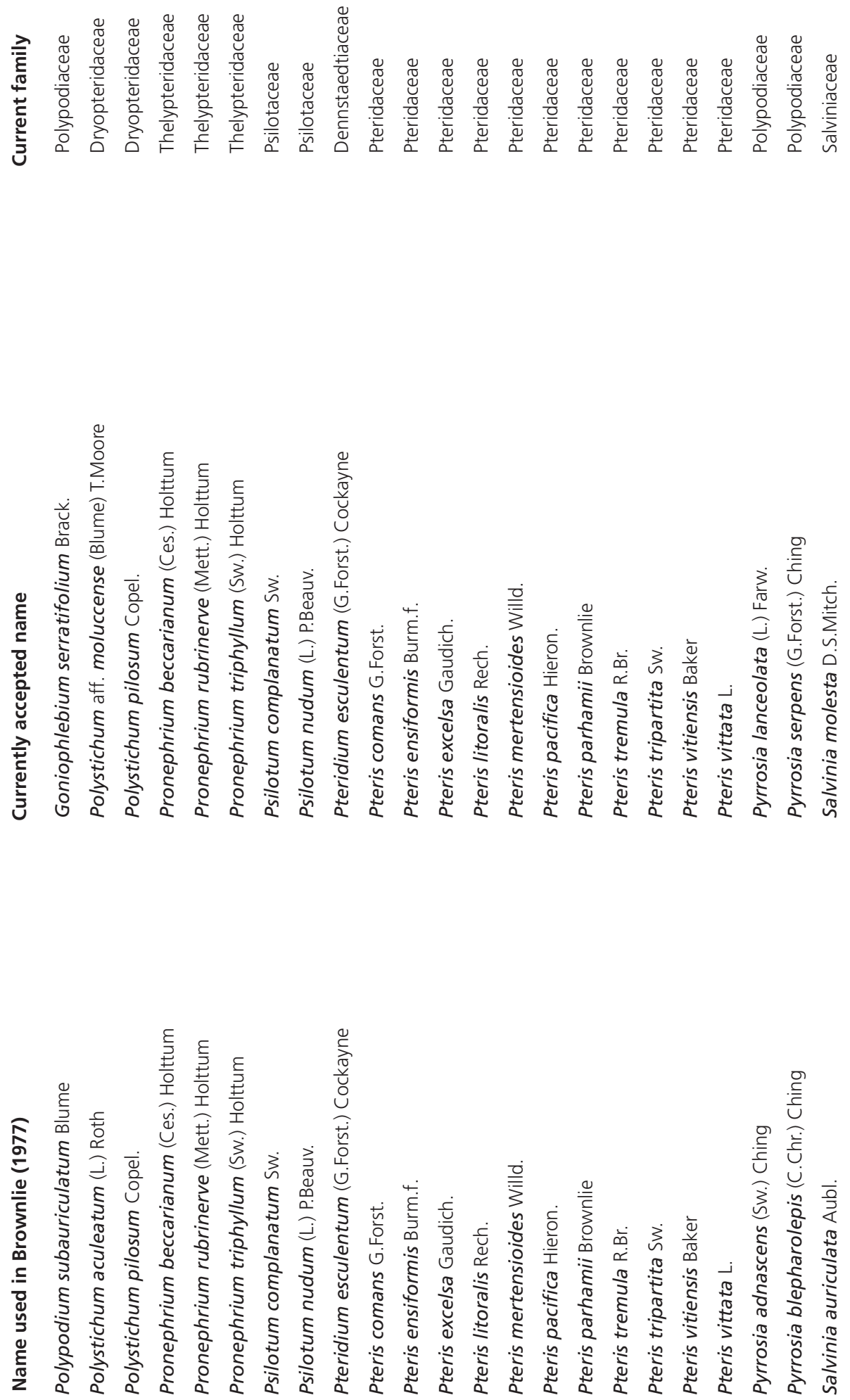

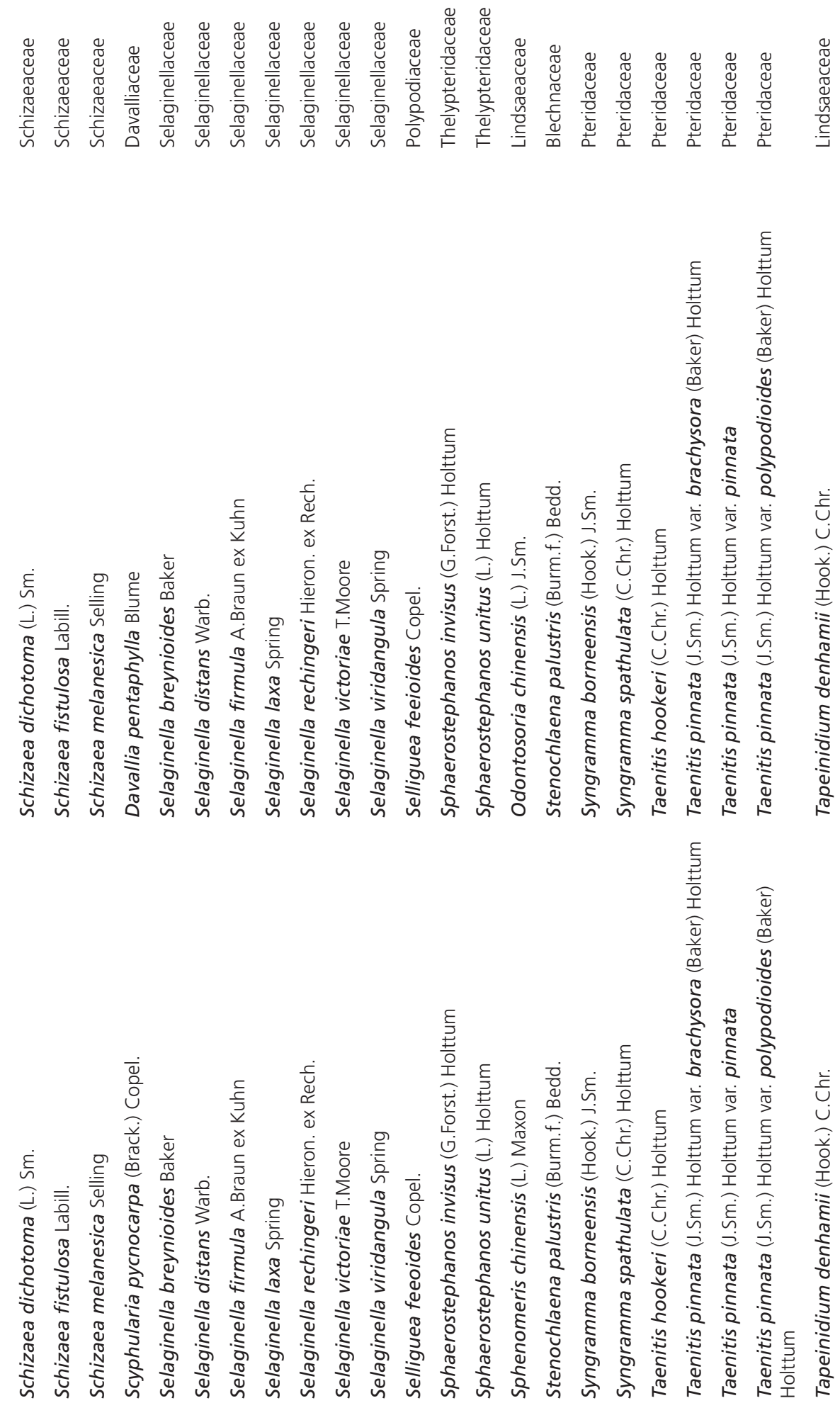

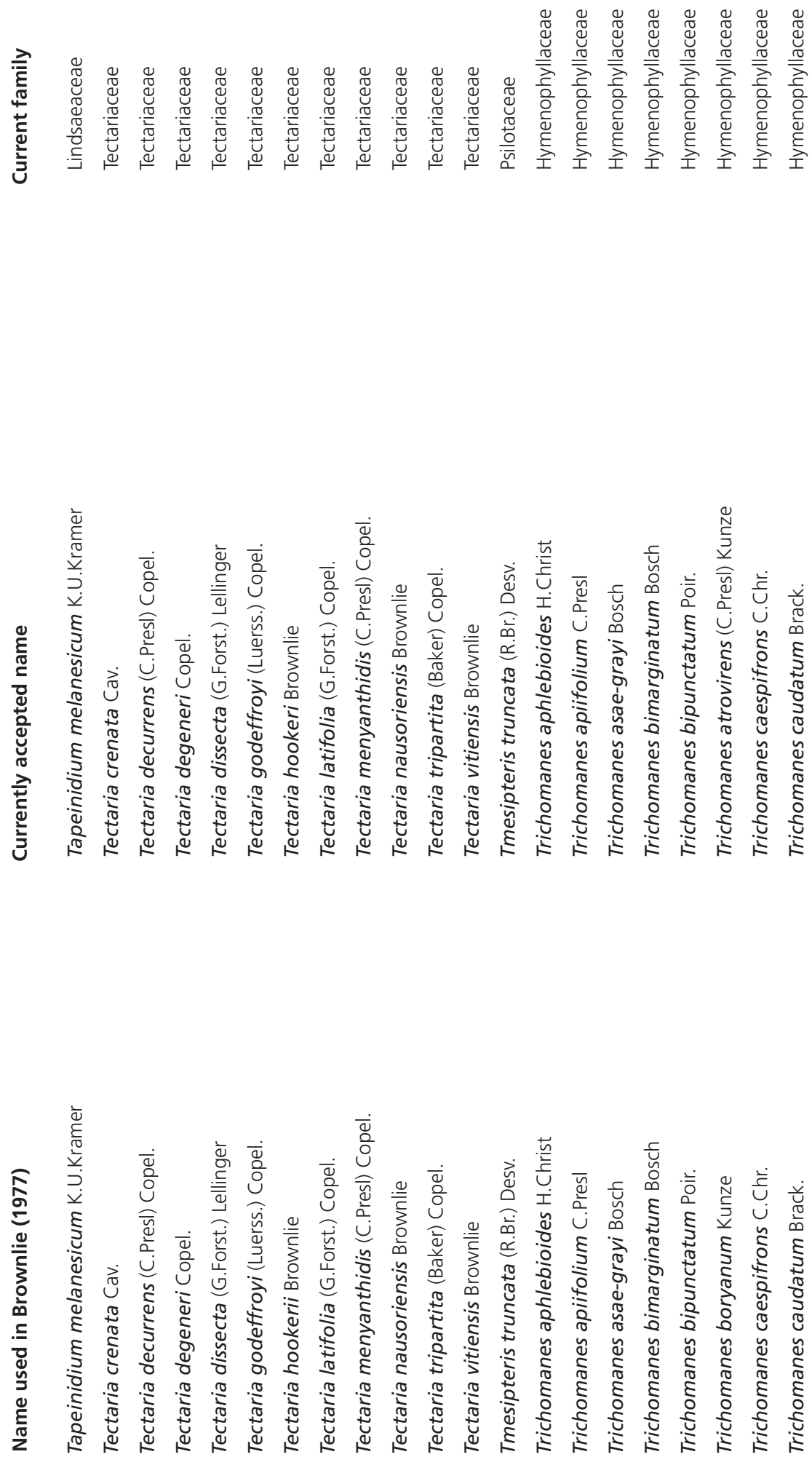

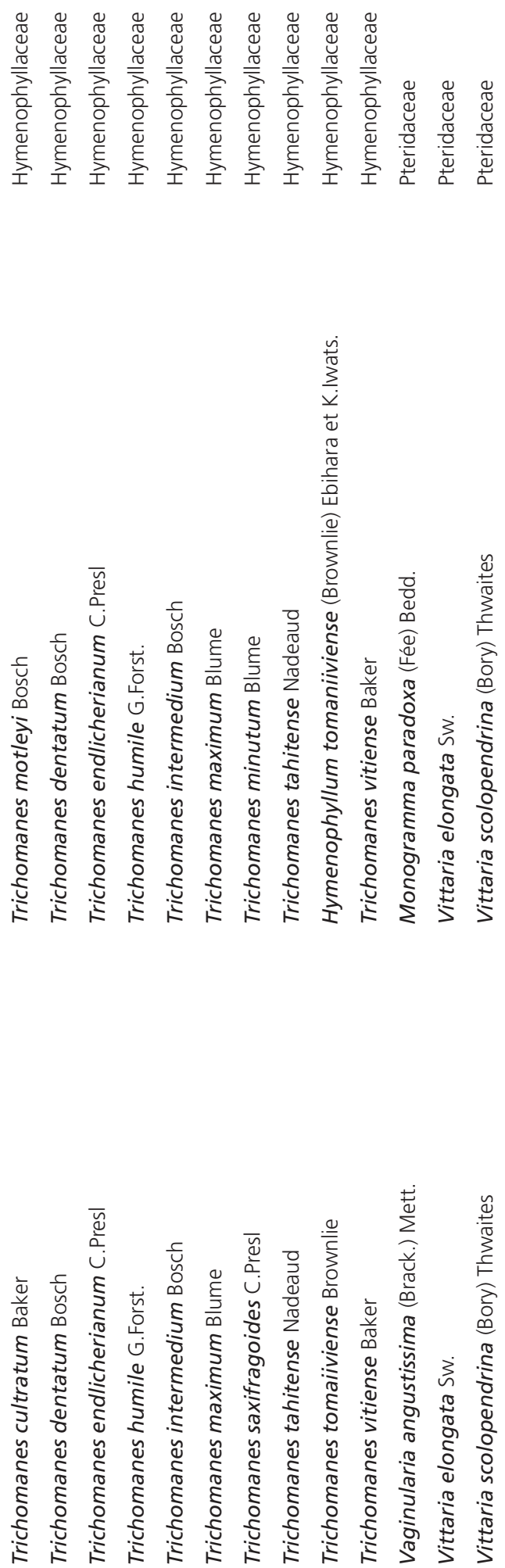


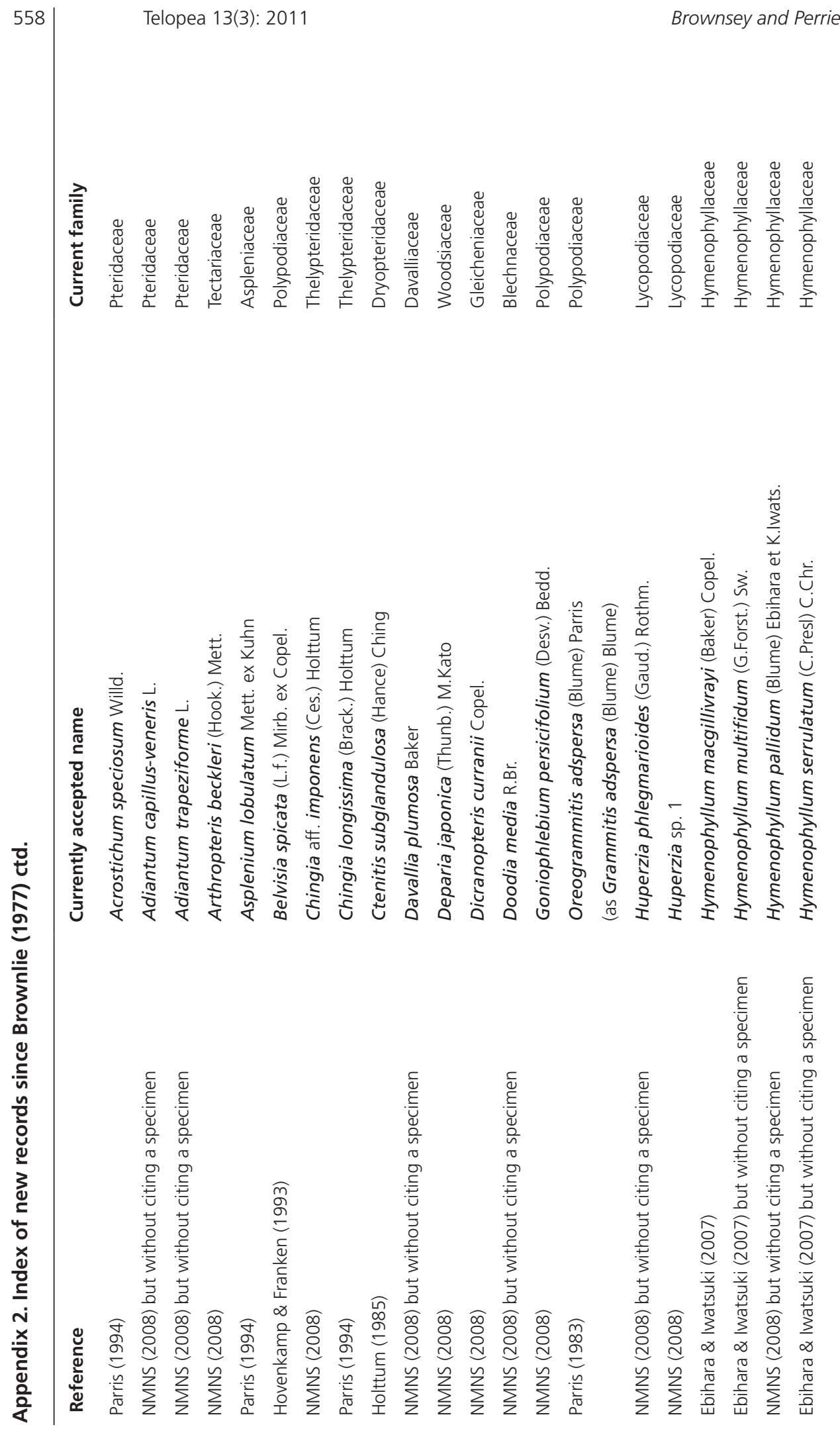



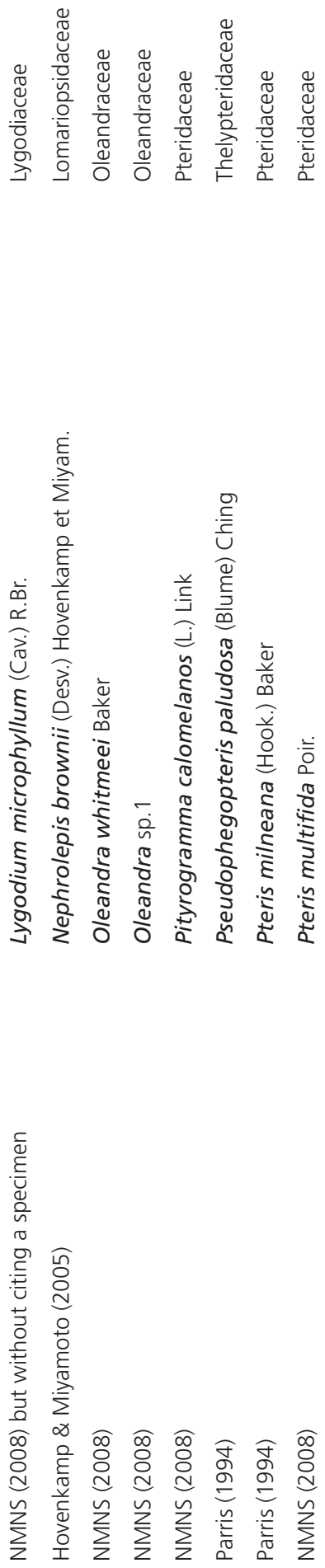

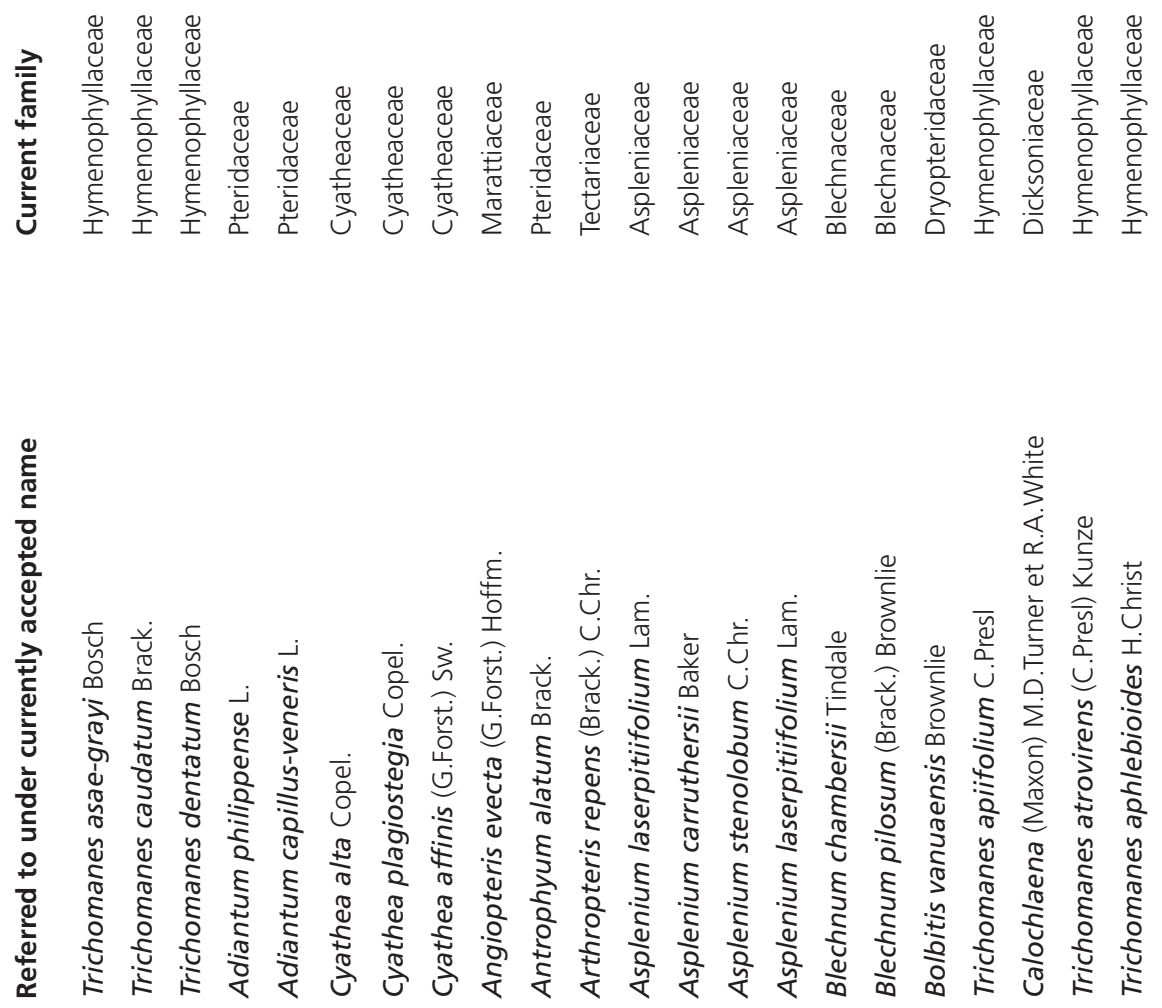

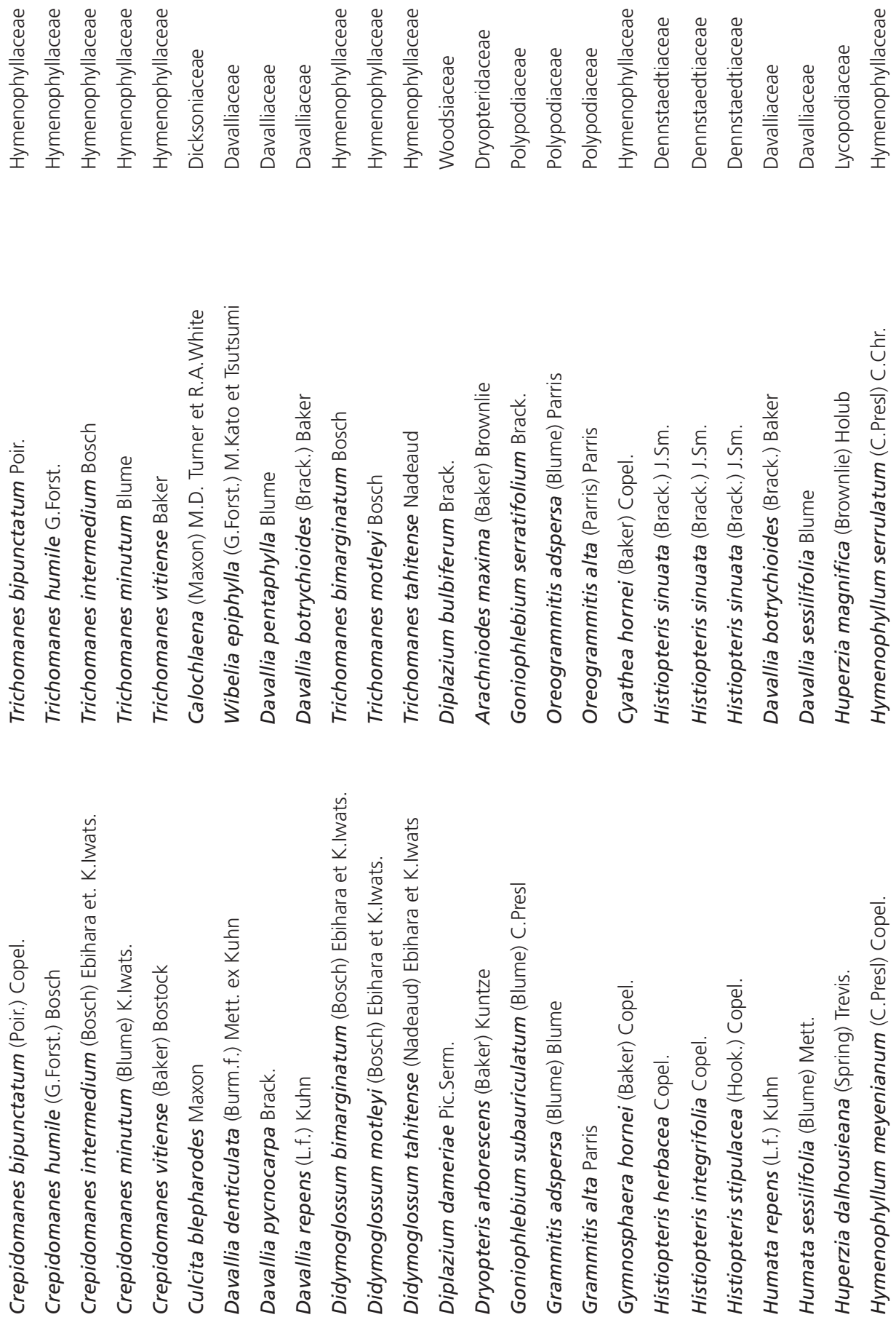

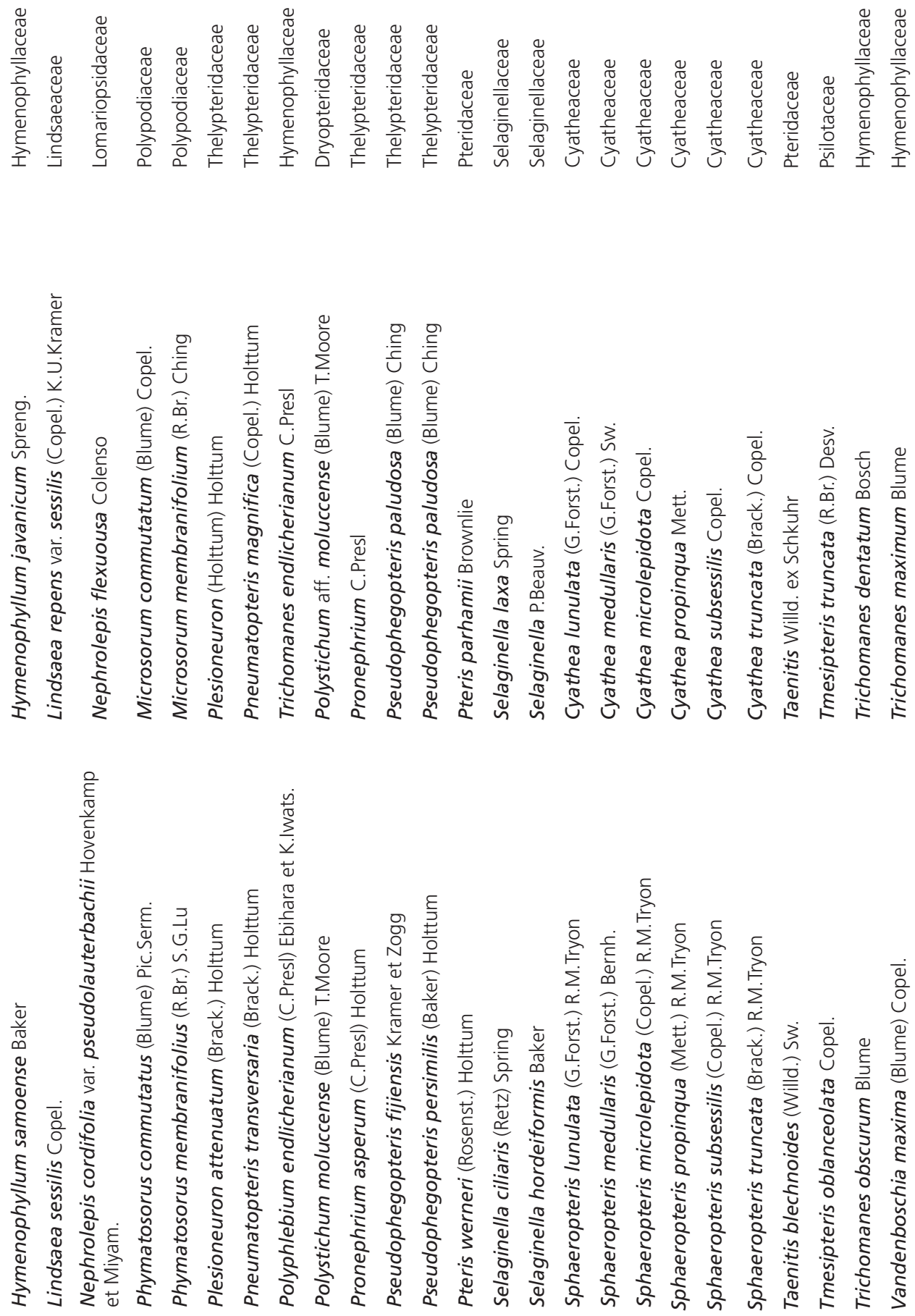